\title{
Endangered European Municipalities: A Systematic Outline of the Problem and Its Political Impact ${ }^{1}$
}

\author{
JAKUB HORNEK
}

\section{sciendo}

Politics in Central Europe (ISSN: 1801-3422)

Vol. 15, No. 2

DOI: 10.2478/pce-2019-0016

\begin{abstract}
Drawing on the experiences of Czech municipalities that cannot perform their local government role due to grave indebtedness, this article seeks to identify other European countries where municipalities may be facing existential problems. It can be assumed that grave indebtedness is not the only potential threat to communities in Europe. One aim of this study is, thus, to identify other possible threats to municipalities and provide specific examples. My goal, among other things, is to start a scholarly discussion about endangered municipalities and bring this phenomenon into the realm of political science. My methodology uses qualitative research and content analysis to identify potential threats that could in extreme cases wipe out European municipalities. To obtain data about specific endangered municipalities in Europe, I rely on snowball sampling, a method used by researchers to identify potential subjects who may be hard to locate. My findings identify five potential threats to European municipalities, which I divide into two groups: common and less common. I highlight the locations of endangered municipalities and those where problems are pending as well as the groups of municipalities in the greatest peril from individual threats. I also highlight potential political impacts. My approach uses empirical case studies to model possible scenarios. Based on this analysis and the experiences of specific endangered municipalities, I outline six general forms of endangerment and eight different courses of municipal endangerment.
\end{abstract}

Keywords: endangered European municipalities; problems of municipalities; gravely indebted municipalities; very small municipalities; threatened by disasters

1 This study has been undertaken as part of project no. 126915 „Failed Municipalities in the Czech Republic" based on the support of the grants department of Charles University, Prague, Czech Republic. 


\section{Introduction}

I want to begin with the example of Prameny, a small municipality located not far from the geographical centre of Europe ${ }^{2}$ and a place where local candidates waived their right to stand for office in each of the six elections held between 2009 and 2012. The reason for this was simple: the longstanding grave indebtedness of the municipality. ${ }^{3}$ During this leadership vacuum, Prameny was run by a state-appointed official who had no power to manage municipal debts or make decisions on the municipality's behalf. At the time, the municipality faced foreclosure and the sale of its property, and by 2011, its debts had skyrocketed to EUR 3.4 million. As a result of this financial deterioration, it ceased to provide public services. By 2016, it had been forced to shut down its municipal lighting system and its sewerage infrastructure was in disrepair, causing problems for residents. At the time of writing, the municipality is still unable to respond to these issues and only the help of local volunteers is allowing it to maintain appearances. Its annual income is approximately EUR 63,000. In contrast, Prameny is charged annual interest of at least EUR 185,000 on a total debt of EUR 4.44 million (Spěváčková 2016; Dolanská 2016). The only change in recent years has been the willingness of some locals to stand in the five successive elections since 2012. ${ }^{4}$ These representatives have not, however, been able to influence the outcome of the situation. A total solution remains far-off, with state involvement the most likely remedy. Prameny is a prime example of a Czech municipality whose very existence is in danger or, to put this differently, it is a place where local self-government may disappear because of longstanding grave indebtedness. Other Czech municipalities in this predicament include Turovice, Bublava and Měnany.

The problem of endangered municipalities in Europe has been neglected to date though there are some examples of research and expert discussions on closely related topics. ${ }^{5}$ Starting a discussion on this topic is particularly important for Czech analysts as it may provide some critical European context for local developments. Gravely indebted small Czech municipalities now find

2 Located in the Karlovy Vary region of the Czech Republic, Prameny is only 20 kilometres from a historic Mittelpunkt Europa (geographic midpoint of Europe).

3 For the purpose of this article, a critically indebted municipality is one that is unable to repay very large debts over an extended period.

4 Extraordinary elections were held on 7 April 2012, 26 September 2015 and 6 January 2018 after the resignation of representatives who were unable to agree on a debt management process. The last such resignation took place in March 2018, that is, six months before the regular municipal elections. Since those elections, the number of elected councilor positions has been from five to nine in the 120-member Prameny council. This is in order to prevent the council's dissolution in the event that individual councillors resign over differences in opinion over how to run the municipality.

5 Examples of paralysed municipalities can also be found in Kenya, South Africa and India among other countries (Blore - Devas - Slater 2004; Marrian - Magubane 2014; Enca 2015). Due to the varying definitions of municipalities globally, however, examples from Europe provide a more suitable comparison. 
themselves in a deadlock which is reinforced by a legislative vacuum since the governing legislation offers no effective solutions (Hornek 2016: 246; Hornek 2017: 116). Expansion of the scope of research beyond the Czech Republic is crucial if we are to understand the phenomenon of endangered municipalities. Aside from this expansion of geographic scope, more investigation is needed of circumstances that may imperil municipalities since grave indebtedness is presumably not the only threat to the existence of European municipalities.

\section{Aims}

To date, political science has not generally addressed the existential problems and potential extinction - of European municipalities. This is probably because these issues implicate many scientific disciplines and their interdisciplinary nature has overshadowed the innate links with political science. Against this backdrop, the study aims to draw attention to key issues and provide a basic systematic outline of factors that may in extreme cases threaten the existence of European municipalities. ${ }^{6}$ At the same time, I describe some of the potential political impacts of these threats. These goals are complicated by the relative poverty of available data on these issues. ${ }^{7}$ One of this work's additional aims is, thus, to provide concrete examples of endangered European municipalities.

\section{Scope, methods applied and data collection}

As my title suggests, Europe provides the geographical boundary for this research. There are, however, more than 90,000 municipalities in Europe (Eurostat 2017). Moreover, across different countries, these municipalities have different functions, are funded differently and vary overall in terms of municipal structures, historical practices and local peculiarities. The aim of my research was therefore to address the greatest possible range of situations that endanger municipalities. As such, no fixed sample of countries was defined in advance and nor was any specific European region investigated. This goal was, however, impeded by the limited availability of source material (see my notes on the data collection process below). The lack of case studies about this phenomenon was similarly unhelpful.

6 The threats in question could significantly affect municipal operations. They may, for example, influence local politics and the provision of municipal services or, in extreme cases, lead to the dissolution of the municipality.

7 The difficulties in obtaining data can be linked to the fact that specific cases of endangered municipalities are often hidden in the international environment where the focus is on the national level. In other words, these cases do not appear in the international (English language) press, and they are not addressed in international analysis/research in political science. 
The study draws on qualitative research methods and a content analysis of relevant sources to meet its objectives (see Yin 2015; Drulák et al. 2008). I have used snowball sampling to obtain data about specific endangered municipalities in Europe. This is a method employed by researchers to identify potential subjects in studies where subjects are hard to locate (Hartnoll 2003). ${ }^{8}$ As a first step, a content analysis was carried out on texts from different scientific disciplines accessible through scientific databases..$^{9}$ I also searched for broadly related book-length works, especially in European libraries and their databases, ${ }^{10}$ and then analysed the volumes found. Based on this literature review, it became clear that a) existing scientific works do not deal with the existential problems of European municipalities in a comprehensive way, b) coverage of the issues of endangered municipalities is fragmented across the scholarly disciplines and c) there are a small number of relevant case studies and more information is needed from these affected municipalities. ${ }^{11}$

Based on these findings, I surveyed a large number of authorities and institutions from a range of European countries. A questionnaire concerning the current issues of municipalities was prepared and sent out to the official e-mail addresses of these institutions. To this end, I contacted 48 unions and associations of municipalities and 95 interior ministries or authorities responsible for particular municipalities ${ }^{12}$ as well as 29 embassies operating in the Czech Republic. The response rate from these institutions was very low at just $9.88 \% .^{13}$ The answers that I received confirmed the need to focus primarily on media reports since even at the level of individual states (regions), there was no clear database or record of problems affecting municipalities, let alone specific case

8 For this reason, the examples and cases presented in this study do not fully reflect the situation across the whole continent. Rather they simply provide a basic systematic analysis. The goal here is to initiate a multidisciplinary discussion, which should lead to broader reflections on these issues.

9 They included electronic sources placed, for instance, in the databases of the Web of Science, Taylor \& Francis Online, Scopus, PoEBSCOhost, Central and East European Online Library or Google Scholar.

10 For this purpose, I made use of libraries at the following universities: Leiden University; University of Warsaw; University of Potsdam; Humboldt University; University of Basel; University of Zurich and Vrije Universiteit Brussel.

11 In addition, I had the opportunity to consult several foreign experts on municipal policy and municipalities. In this regard, I discussed potential threats to municipalities with Professor Jochen Franzke (University of Potsdam), Professor Pawel Swianiewicz (University of Warsaw), docent Daniel Klimovský (Comenius University in Bratislava) and the staff of Gemeindeamt of Canton of Zürich Dr. Alexander Gulde (Department of Municipal Finance) and Dr. Alexander Locher (Legal Secretary).

12 In the case of federal (regional) states, I approached all relevant ministries (authorities) in the state responsible for the municipality.

13 Most (10) of the completed answers came from the embassies. The authorities and relevant ministries that were contacted responded in five cases. And only two unions of municipalities - the Association of Estonian Cities and the Croatian Association of Municipalities, replied from the union of municipalities. All the answers received had the following two characteristics: (a) a recommendation that the author approach a specific institution (the institutions addressed did not respond); or (b) references were sent to possible information that could be used for research. 
studies. I therefore conducted an online search of European media ${ }^{14}$ with the goal of finding concrete examples of endangered communities. ${ }^{15}$ From this monitoring, I was able to map out some examples of endangered European municipalities that had been covered in the media. ${ }^{16}$ At the same time, the information about individual threats and their impacts remained fairly basic, and I therefore attempted to obtain more information directly from the representatives of the affected European municipalities. Unfortunately, this did not produce the desired results. ${ }^{17}$

Drawing on all of the data processed and examples collected, I proceeded to identify and categorise dangers. Based on their potential intensity, they were divided into two groups: threats more likely to occur in Europe and those that were less common and limited to specific circumstances or fortunately not encountered at all in Europe. Individual threats were linked to specific examples of municipalities and states where they might be happening or arise in the future. For each individual threat, I identified situations that might arise and pointed to examples of potentially affected municipalities. This study concludes by proposing some general concepts that could be used to characterise the situations endangered municipalities may face. Applying these terms, I outline eight possible variations on how municipalities could become endangered.

14 The following databases were consulted: Factiva, LexisNexis, PressReader and Newton Media Search. I used the Google search function to monitor the media. (list key words?)

15 Media monitoring has shown that if the media do cover problematic municipalities, then it is in texts that are not - with some exceptions - published in the English language. Because it is a local theme, it is not necessary to present it in English, but only in specific national languages. For this reason, it is a great advantage for the researcher to cover as many European languages as possible with his or her linguistic skills. For the sake of further research and inquiries, it is advisable to make even greater efforts to cooperate with local institutions and researchers who can better focus on possible cases from their countries. The author of the paper worked mainly with the texts written in Central European languages, i.e. Czech, German, Slovak, Polish and, of course, English. Nevertheless, some French, Spanish, Italian and Hungarian texts have been incorporated as well.

16 The used examples mainly cover the situation after 2001, but the paper also treats the examples of municipalities prior to this period, on the grounds that such threats may also occur in the future.

17 Representatives of 20 municipalities (from Slovakia, Germany, Austria, Switzerland) were addressed, mainly from small municipalities. The representatives were approached in their native languages and were asked to respond to eight questions related to local politics, citizens' participation in local politics, administrative capacity of the municipality or, for instance, services provided by municipalities. They were addressed first through official or personal emails. However, no answers came back, probably also for the following reasons: many of these municipalities do not have their own websites, the representatives of the addressed municipalities are not released from their jobs and hold their functions in their leisure time, and in some cases it is even impossible to find out via the Internet who the specific representatives are. That is why they were addressed for the second time, this time by letters sent by post (it was often difficult to obtain the official addresses of the municipal authorities and, therefore, higher administrative units were addressed). This effort, nevertheless resulted in one answer received from the Swiss municipality Meienried. 


\section{State of knowledge and terminology applied}

Much has been written about the miscellaneous problems of municipalities and the challenges they have had to face ${ }^{18}$ Even so, the scholarship concerning the existential problems of European municipalities is not comprehensive. In particular, there is a need to define what constitutes a threat to municipalities and decide how to approach this issue. The issue of potential existential threats to municipalities has been addressed across a wide range of disciplines including economics, law, public administration, sociology, geography and urban studies. Individual disciplines perceive these potential threats differently according to their focus.

I want therefore to focus on the current state of knowledge about municipal endangerment. This includes the questions of whether and how the problem has been addressed by political scientists, how the research deals with natural and environmental threats and how demographics and economics factor into these risks. From an economic point of view, the most significant threat to municipalities is indebtedness. When municipal representatives fail to manage finances carefully, the community may be left with financial problems severe enough to threaten its existence. Generally speaking, the largest cities with the biggest budgets have the highest volumes of total debt. These cities can, however, afford to borrow large amounts and tend to be able to repay these sums as a result of having more diversified incomes. In contrast, though the debts of smaller municipalities may not to be as high as those of large cities, in cases where they are large, communities have a hard time repaying them. ${ }^{19}$ Financial crises (CEMR 2009; UCLG 2009) also have an impact on municipalities ${ }^{20}$ and can create or exacerbate debt repayment problems. This is what has happened, for example, in the cities and regions of southern Europe where the inability to repay debts deepened during the financial crisis and where development models proved unsuccessful (Knieling - Othengrafen 2016). The research also covers

18 Examples include: municipal reforms in a number of European countries that have merged many municipalities; the democratisation itself in the countries of Central and Eastern Europe; the effects of globalisation or regionalisation; broadening the direct election of mayors in many European countries; using new methods such as New Public Management or practicing the principles of Multi-Level Governance; the use of the concept of paradiplomacy by large municipalities in particular; or a relatively new concept of smart cities that is expected to introduce modern technology into city management so that municipalities, for example, make more efficient a provision of public services, the areas of energy, transport, waste management, water management and, as a whole, all of that should facilitate a better way to sustainable development.

19 When publishing the most indebted municipalities in a given country, the total debt is converted per capita, which makes it possible to compare the situation across various size categories. That is the reason this text also uses this conversion.

20 For example, in 2011, the Council of Europe released a publication dealing with local governments during the crisis. The texts arose from the 17th Session of the Council of Europe Conference of Ministers Responsible for Local and Regional Government, held in Kyiv, on 3-4 November 2011 (Davey 2012). 
municipal finance reforms and case studies of cities with economic problems (Hansmann 2011). Other works deal, for example, with strategies to escape municipal debt taps (Junkernheinrich 2011) in the absence of municipal funds (Holtkamp 2011; Holtkamp 2010). The authors also address factors affecting local policies on the consolidation of the municipal budgets (Geißler 2011) and the options for declaring municipal bankruptcy (municipal insolvency), which might be one solution to grave municipal debts (Brand 2014) ${ }^{21}$

The second research perspective devoted a great deal of attention from the international community and can often be linked to indebtedness, too. It entails demographic problems of municipalities, which may be caused by a variety of influences, such as migration, urbanization, suburbanization, mobility, the aging of the population or indebtedness (ed. Oswald 2006). In this area, the international scientific community deals with the long-term or medium-term leaving of citizens from their residences. This phenomenon is referred to by the term 'shrinking cities'. Municipalities such as these can be found all over the world. It can be a global process, or a purely regional phenomenon (ed. Oswallt 2004; ed. Oswallt 2006; ed. Weaver - Bagchi-Sen - Knigh - Frazier 2017). In Europe, this municipal shrinking was and still is occurring, for example in connection with the new states of Germany (German Länder) and the cantons of Switzerland. The phenomenon of shrinking cities is not unusual or new and can be found in ancient times (Richter 2013: 21). For example, Bartl (2011) explains the shrinking of municipalities by the migration and aging of the population. The correlating decrease in population has an impact on municipal budgets. On that account, these municipalities can go into debt, their development might deteriorate, and the services could be restricted, including health care. In extreme cases, municipalities would have no human resources for management and no candidates for elections (Bartl 2011). In Europe, case studies have been developed on this issue, mainly concerning German municipalities. These studies also address the influence on local community policy but mainly focus on fields such as Urban Studies, Economy and Sociology. This paper is particularly concerned with urban regeneration and the potential of the shrinking municipalities (Kühn - Liebmann 2009; Richter 2013). It deals with the specific cases of German cities, ${ }^{22}$ such as Duisburg, Zittau, Görlitz, Eisenhüttenstadt, Riesa, Stalsund, as well as with the theoretical approaches and concepts of how to aid municipalities in regeneration, for example, through strategic planning, multi-

21 The text deals with the situation in Germany. In the Czech Republic (given the cases of critically indebted municipalities), the situation was dealt with by the relevant ministries, but eventually this step never materialised. In Europe, bankruptcy of municipalities is possible, for example, in Switzerland or Hungary. (Hornek 2016)

22 The research does not only concern German cities but also shrinking municipalities all over the world, for example cities from deindustrialisation in Great Britain, suburbanisation in the USA or cities affected by the collapse of the Soviet Union. (ed. Oswald 2004; ed. Oswald 2006) 
level governance or urban redevelopment (eds. Kühn - Liebmann 2009; Glock 2006). The researchers also address natural and environmental catastrophes and their impacts on municipalities. However, also in this case and more importantly, they address the impacts on human lives and property. Typically, current disasters cause more property damage and affect a larger area and thereby more population (Langhammer 2007: 13). Since the year 2000, about two billion people around the world have been directly affected by natural disasters (eds. Guha-Sapir - Santos 2013). Both natural and social sciences are exploring disasters and their impact on society. Geography has been addressing such areas as disaster risk, disaster vulnerability (Wisner - Luce 1993), disaster risk reduction and public management in critical situations (Schneider 2011) for a long time. The economic impacts of natural disasters are also explored (Guha-Sapir - Santos 2013). Case studies often target African cities (e.g. Pelling - Wisner 2014) and large natural disasters in the US and their impact (e.g. Schneider 2011).

In political science, the issue of threats to municipalities has not yet been given much regard. There are no case studies to identify the political impacts of various threats in specific municipalities. ${ }^{23}$ Consequently, it is not yet possible to rely on typology or classification that would deal with the threats and their possible political impacts. Also, for example, no institution creates a possible index of the most endangered municipalities. The phenomenon of failed states has such an index, called the Fragile States Index (FFP 2016). The fact that political scientists have not yet sufficiently addressed the threats that may endanger the existence of local governments or their political impacts also means that there is no agreed-upon terminology that would be used or that would describe the above-mentioned phenomenon. ${ }^{24}$

The text proposes using the term 'endangered municipalities' as an example of municipalities that may be afflicted by a particular threat that could eventually bring the municipality to extinction. Neither do we find a generally applied terminology in the case of such municipalities that do not fulfill their functions anymore, are paralyzed and lack an elected municipal leadership, as was the case with the Czech municipality of Prameny between the years 2009-2012. For such municipalities, the term 'failed municipalities' is suggested, based on the example of states that do not fulfill their basic functions. ${ }^{25}$ However, the term

23 For example, no papers have yet been published to explain how the local politics of a municipality (voter turnout, local election campaigns, etc.) is affected or not after the municipality has suffered a natural-environmental disaster. There is also a lack of more detailed research into the critical debt of municipalities and its influence on local politics (cf. Hornek 2016). Also, political analyses of local policies of the shrinking municipalities are inadequate.

24 However, even other fields which deal with the issues of municipalities do not have proper terminology, except for the aforementioned phenomenon of shrinking municipalities.

25 Theoretical approaches to the failed states can be found at three levels, namely economic, political and military-security (cf. Šmíd - Vad'ura 2009). It is the economic and political decline that could possibly be applied to the municipalities. 
failed municipalities is not yet used in political science. ${ }^{26}$ It is only mentioned in one economic publication devoted to non-European municipalities from the authors Blore, Devas and Slater (2004). The authors divide the municipalities into four categories, ${ }^{27}$ where the fourth type describes the municipalities that have failed. However, this is a typology of the third-world communities whose leadership is not elected but appointed. These municipalities have deficit budgets, which is a problem that is not being solved. Central governments can proceed in such cases by removing the remaining functions from the failed municipalities. This is an approach that has been applied, for example, in Kenya and some South Asian countries ${ }^{28}$ (Blore - Devas - Slater 2004). In European literature, this terminology does not otherwise exist. The situation is different in the US literature, where essentially the same term of failure of municipalities is used. The term is mainly associated with American municipalities that have financial problems or have gone bankrupt ${ }^{29}$ (Schragger 2016). However, even in the US, scientists are more concerned with the economic (Spiotto - Acker - Appleby 2012) rather than political science. They deal with the prevention of critical debt (Frankel 2014) and the possible reforms that would solve the problems of bankruptcy (Gillette - Skeel 2016).

\section{The identified threats to European municipalities}

Based on the above described procedure and data collection, 5 types of threats that can significantly jeopardise the European municipalities have been identified and differentiated. The paper first deals primarily with three threats, which it dedicates the main space to. These are the following threats 1) economic, 2) demographic and 3) natural-environmental. ${ }^{30}$ They are labeled as rather com-

26 The terms 'endangered municipalities' and 'failed municipalities' should be logically complemented by a term that denotes such municipalities that have failed to deal with the impacts of endangerment and de iure (not only de facto as in the case of failed municipalities) they cease to function and exist. Such municipalities can be described as 'extinct municipalities'.

27 The remaining municipalities are categorised as dynamic, handicapped and frustrated (Blore - Devas Slater 2004: 14-16).

28 A precondition for the solution to the described issues in municipalities is to secure new financial resources and to revive local democratic responsibilities. This, however, appears to be a long-term process.

29 This is the case of such municipalities as Detroit, Stockton, Vallejo San Bernardino or Bell. These are mainly post-industrial cities, which are a part of the non-prosperous regions. In the affected cities there is a large ethnic minority (Schragger 2016: 23). In the USA, they have had experience with the bankruptcy of municipalities since 1937. By January 2012, 633 bankruptcies of municipalities and small tax districts had been recorded in the US. The debt limit differs for each municipality according to the federal states (Spiotto - Acker - Appleby 2012: 47).

30 Many possible threats may fall under natural-environmental threats. The paper focuses on those that can be so severe that municipalities may become extinct due to them. They primarily include threats from volcanic activity, earthquake threats, or the possibility of a nuclear power plant accident. In addition, they also include, for example, threats such as floods, devastating fires, tsunamis, landslides and chemical industrial accidents. 
mon threats because they can afflict potentially more European municipalities than the other two threats. Nevertheless, the other two types of threats, which are rather rare, namely include 4) a higher intent and 5) a war conflict, and are naturally represented in the paper as well. Such threats form the group of less common threats and the text attaches less attention to them, as these threats exhibit a very specific local character; in other words, fortunately, such threats do not exist in Europe.

Table 1 summarises the identified threats to European municipalities. In the table, examples of states and specific municipalities, where we may encounter endangered municipalities or where they might appear in the future, have been assigned to individual threats.

\section{Table 1: Types of threats and examples of endangered or potentially endangered municipalities}

\begin{tabular}{|c|c|c|c|c|c|c|c|c|}
\hline \multirow{2}{*}{$\begin{array}{c}\text { 1) } \\
\text { Economic } \\
\text { threats } \\
\text { (grave } \\
\text { indebted- } \\
\text { ness) }\end{array}$} & \multicolumn{2}{|c|}{$\begin{array}{c}\text { 2) } \\
\text { Demographic } \\
\text { threats }\end{array}$} & \multicolumn{4}{|c|}{$\begin{array}{c}\text { 3) } \\
\text { Natural and environmental threats }\end{array}$} & \multirow{2}{*}{\begin{tabular}{|c|}
$\begin{array}{c}\text { 4) } \\
\text { Threats } \\
\text { from } \\
\text { plans at } \\
\text { a higher } \\
\text { level }\end{array}$ \\
a) con- \\
struction \\
of strategic \\
buildings \\
in the area \\
of the \\
municipa- \\
lity or b) \\
mining \\
\end{tabular}} & \multirow{2}{*}{$\begin{array}{c}\text { 5) } \\
\text { Threats } \\
\text { from } \\
\text { military } \\
\text { conflict }\end{array}$} \\
\hline & $\begin{array}{l}\text { a) very small popu- } \\
\text { lation in the muni- } \\
\text { cipality }\end{array}$ & $\begin{array}{c}\text { b) shrinking } \\
\text { municipalities } \\
\text { (more than } \\
20 \% \text { of the } \\
\text { population) }\end{array}$ & $\begin{array}{l}\text { a) threat } \\
\text { of floods }\end{array}$ & $\begin{array}{l}\text { b) threats } \\
\text { from } \\
\text { volcanic } \\
\text { activity }\end{array}$ & $\begin{array}{l}\text { c) threat } \\
\text { of earth- } \\
\text { quakes }\end{array}$ & $\begin{array}{l}\text { d) risk of } \\
\text { a nuclear } \\
\text { power } \\
\text { plant acci- } \\
\text { dent }\end{array}$ & & \\
\hline $\begin{array}{l}\text { Examples of } \\
\text { countries/ } \\
\text { municipa- } \\
\text { lities }\end{array}$ & $\begin{array}{l}\text { Examples of } \\
\text { countries/ } \\
\text { municipalities }\end{array}$ & $\begin{array}{l}\text { Examples of } \\
\text { countries/ } \\
\text { municipa- } \\
\text { lities }\end{array}$ & $\begin{array}{l}\text { Examples } \\
\text { of count- } \\
\text { ries }\end{array}$ & $\begin{array}{l}\text { Examples of } \\
\text { countries/ } \\
\text { municipa- } \\
\text { lities }\end{array}$ & $\begin{array}{c}\text { Examples } \\
\text { of count- } \\
\text { ries }\end{array}$ & $\begin{array}{c}\text { Examples of } \\
\text { countries }\end{array}$ & $\begin{array}{l}\text { Examples } \\
\text { of count- } \\
\text { ries }\end{array}$ & $\begin{array}{l}\text { Examples } \\
\text { of count- } \\
\text { ries }\end{array}$ \\
\hline $\begin{array}{l}\text { Austria } \\
\text { (Dünserberg, } \\
\text { Warth, } \\
\text { Schröcken, } \\
\text { Damüls, St. } \\
\text { Gerold, Klös- } \\
\text { terle); Czech } \\
\text { Republic } \\
\text { (Prameny, } \\
\text { Turovice, } \\
\text { Bublava, } \\
\text { Dlažkovice) } \\
\text { France (Le- } \\
\text { vallois-Perre); } \\
\text { Germany } \\
\text { (Gröde, Put- } \\
\text { garten, Damp, } \\
\text { Langeness, } \\
\text { Hagen } \\
\text { Duisburg); }\end{array}$ & $\begin{array}{l}\text { Austria (Gramais } \\
\text { [45 inh.], Namlos } \\
72 \text { inh.], Kaisers } \\
76 \text { [inh.], Hinter- } \\
\text { hornbach [92 inh.], } \\
\text { Großhofen [98 } \\
\text { inh.]); Czech Re- } \\
\text { public (e.g. [Čilá } 15 \\
\text { inh.], Vysoká Lhota } \\
\text { [15 inh.], Kaničky } \\
\text { and Hradiště [each } \\
27 \text { inh.], Kuřimany } \\
\text { [28 inh] or Bludov } \\
\text { [29 inh].); France } \\
\text { (e.g Rochefourchat } \\
\text { [1 inh.], Leménil-Mi- } \\
\text { try [3 inh.], Rouv- } \\
\text { roy-Ripont [7 inh.], } \\
\text { Urtière [8 inh.], }\end{array}$ & \begin{tabular}{|l|} 
Austria \\
(Eisenerz); \\
Germany \\
(Düsseldorf, \\
Bitterfeld- \\
Wolfen, \\
Gelsenkir- \\
chen, Görlitz, \\
Halle); Por- \\
tugal (Arraio- \\
los, Lisbon); \\
Greece \\
(Athens, Pi- \\
raeus), Spain \\
(Baracaldo); \\
Great Bri- \\
tain (Belfast, \\
Birkenhead, \\
Glasgow, \\
Liverpool);
\end{tabular} & \begin{tabular}{|l|} 
across \\
European \\
countries
\end{tabular} & $\begin{array}{l}\text { Greece; (e.g. } \\
\text { Agioi Theo- } \\
\text { doroi, Santo- } \\
\text { rini, Nisyros, } \\
\text { Milos, Troizi- } \\
\text { nia-Metha- } \\
\text { na); Iceland } \\
\text { (e.g. Mýrdal- } \\
\text { shreppur or } \\
\text { Bláskógaby- } \\
\text { ggð) Portu- } \\
\text { gal (munici- } \\
\text { palities Vila } \\
\text { do Corvo, } \\
\text { Vila Franca } \\
\text { do Campo, } \\
\text { Ponta Del- } \\
\text { gada, Ribeira } \\
\text { Brava); }\end{array}$ & $\begin{array}{l}\text { Balkan } \\
\text { countries; } \\
\text { Bulgaria; } \\
\text { Greece; } \\
\text { Iceland; } \\
\text { Italy; } \\
\text { Romania; } \\
\text { Turkey }\end{array}$ & $\begin{array}{l}\text { Belarus; } \\
\text { Belgium; } \\
\text { Bulgaria; } \\
\text { Czech } \\
\text { Republic; } \\
\text { Finland; } \\
\text { France; } \\
\text { Germany } \\
\text { Hungary; } \\
\text { Romania; } \\
\text { Slovakia; } \\
\text { Slovenia; } \\
\text { Spain; } \\
\text { Sweden; } \\
\text { Switzer- } \\
\text { land; Ne- } \\
\text { therlands; } \\
\text { Ukraine; } \\
\text { United } \\
\text { Kingdom }\end{array}$ & \begin{tabular}{|l|} 
across \\
European \\
countries
\end{tabular} & $\begin{array}{l}\text { in the } \\
\text { past the } \\
\text { collapse } \\
\text { of Yugo- } \\
\text { slavia, the } \\
\text { present } \\
\text { conflict in } \\
\text { eastern } \\
\text { Ukraine }\end{array}$ \\
\hline
\end{tabular}




\begin{tabular}{|c|c|c|c|c|c|c|c|c|}
\hline \multirow{2}{*}{$\begin{array}{c}1) \\
\text { Economic } \\
\text { threats } \\
\text { (grave } \\
\text { indebted- } \\
\text { ness) }\end{array}$} & \multicolumn{2}{|c|}{$\begin{array}{c}\text { 2) } \\
\text { Demographic } \\
\text { threats }\end{array}$} & \multicolumn{4}{|c|}{$\begin{array}{l}\text { 3) } \\
\text { Natural and environmental threats }\end{array}$} & \multirow{2}{*}{\begin{tabular}{|c|c}
$\begin{array}{c}\text { 4) } \\
\text { Threats } \\
\text { from } \\
\text { plans at } \\
\text { a higher } \\
\text { level }\end{array}$ \\
$\begin{array}{c}\text { a) con- } \\
\text { struction } \\
\text { of strategic } \\
\text { buildings }\end{array}$ \\
in the area \\
of the \\
municipa- \\
lity or b) \\
mining \\
\end{tabular}} & \multirow{2}{*}{\begin{tabular}{|} 
5) \\
Threats \\
from \\
military \\
conflict
\end{tabular}} \\
\hline & $\begin{array}{l}\text { a) very small population } \\
\text { in the municipality }\end{array}$ & $\begin{array}{l}\text { b) shrinking } \\
\text { municipalities } \\
\text { (more than } \\
20 \% \text { of the } \\
\text { population) }\end{array}$ & $\begin{array}{l}\text { a) threat } \\
\text { of floods }\end{array}$ & $\begin{array}{l}\text { b) threats } \\
\text { from } \\
\text { volcanic } \\
\text { activity }\end{array}$ & $\begin{array}{l}\text { c) threat } \\
\text { of earth- } \\
\text { quakes }\end{array}$ & $\begin{array}{l}\text { d) risk of } \\
\text { a nuclear } \\
\text { power } \\
\text { plant } \\
\text { accident }\end{array}$ & & \\
\hline $\begin{array}{c}\text { Examples of } \\
\text { countries/ } \\
\text { municipa- } \\
\text { lities }\end{array}$ & $\begin{array}{l}\text { Examples of } \\
\text { countries/ } \\
\text { municipalities }\end{array}$ & $\begin{array}{c}\text { Examples of } \\
\text { countries/ } \\
\text { municipa- } \\
\text { lities }\end{array}$ & $\begin{array}{l}\text { Examples } \\
\text { of count- } \\
\text { ries }\end{array}$ & $\begin{array}{c}\text { Examples of } \\
\text { countries/ } \\
\text { municipa- } \\
\text { lities }\end{array}$ & $\begin{array}{c}\text { Exam- } \\
\text { ples of } \\
\text { countries }\end{array}$ & $\begin{array}{c}\text { Examples } \\
\text { of count- } \\
\text { ries }\end{array}$ & $\begin{array}{c}\text { Examples } \\
\text { of count- } \\
\text { ries }\end{array}$ & $\begin{array}{c}\text { Exam- } \\
\text { ples of } \\
\text { countries }\end{array}$ \\
\hline $\begin{array}{l}\text { Hungary } \\
\text { (Harkans, } \\
\text { Bükk } \\
\text { szék, Bala- } \\
\text { tonfüzfö); } \\
\text { Italy (Torino, } \\
\text { Milan, Siena, } \\
\text { Genoa); } \\
\text { Poland (Byd- } \\
\text { goszcz, Ptock, } \\
\text { Łódź, Toruń); } \\
\text { Portugal } \\
\text { (Portimão); } \\
\text { Slovakia } \\
\text { (Devín, } \\
\text { Ondavka, } \\
\text { Púchov, } \\
\text { Čadná,); Slo- } \\
\text { venia (Gor- } \\
\text { nji Petrovci, } \\
\text { Solčava); } \\
\text { Spain (Pioz, } \\
\text { Jerez de la } \\
\text { Frontera); } \\
\text { Switzerland } \\
\text { (Leukerbad) }\end{array}$ & $\begin{array}{l}\text { Casterets and Baren } \\
\text { [each 13 inh.], Les } \\
\text { Goulles and Pomme- } \\
\text { rol [each } 19 \text { inh.]); } \\
\text { Germany (e.g. Gröde } \\
\text { [9 inh.], Dierfeld [10 } \\
\text { inh.], Wiedenborstel [11 } \\
\text { inh.], Keppeshausen } \\
\text { [15 inh.], Herbstmühle } \\
\text { and Sengericht [each } \\
19 \text { inh], Grothusen- } \\
\text { koog [21 inh.], Hamm } \\
\text { and Süderhöft [each } \\
22 \text { inh.], Affler [27 } \\
\text { inh.]); Slovakia (e.g. } \\
\text { Príkra [7 inh.], Šarbov } \\
\text { [10 inh.], Havranec [11 } \\
\text { inh.], Ondavka [15 } \\
\text { inh.], Belejovce [18 } \\
\text { inh.], Poproč [23 inh.] } \\
\text { Bystrá and Olšinkov } \\
\text { [each } 27 \text { inh.], Parihu- } \\
\text { zovce [27 inh.], Rege- } \\
\text { tovka [31 inh.]; Spain } \\
\text { (Jaramillo Quemado } \\
\text { [5 inh.], Castilnuevo } \\
\text { [8 inh.], Fuembellida } \\
\text { [13 inh.], Manciles [19 } \\
\text { inh.]; Switzerland (e.g. } \\
\text { Corippo [13 inh.], Bister } \\
\text { [33 inh.], Kammersrohr } \\
\text { [29 inh], Schelten } \\
\text { [40 inh.] Lohn [41 } \\
\text { inh.] Rebévelier [42 } \\
\text { inh.], Berken [43 inh.], } \\
\text { Clavaleyres [46 inh], } \\
\text { Rongellen [53 inh.], } \\
\text { Meinried [71 inh.]). }\end{array}$ & $\begin{array}{l}\text { Italy (Cagli- } \\
\text { ari, Forno di } \\
\text { Zoldo, Genoa, } \\
\text { La Spezia); } \\
\text { Latvia } \\
\text { (Liepaja); } \\
\text { Slovenia } \\
\text { (Maribor) }\end{array}$ & & $\begin{array}{l}\text { Italy Messi- } \\
\text { na, Catania } \\
\text { (Etna); Spain } \\
\text { (municipali- } \\
\text { ties Tuineje, } \\
\text { Frontera, } \\
\text { Gáldar, Arte- } \\
\text { nara, Alajeró, } \\
\text { Santa Cruz } \\
\text { de la Palma, } \\
\text { Tinajo, La } \\
\text { Orotava) }\end{array}$ & & & & \\
\hline
\end{tabular}




\section{Rather common threats of municipalities}

\section{Endangerment by critical indebtedness}

The indebtedness of the municipalities varies across individual European countries. In recent years, the local self-government debt in Central and Eastern Europe, such as in Romania and Poland, has rapidly grown. The total debt has also increased in France and in Italy. However, due to the experience with the last economic crisis, the municipalities are attempting to manage their budgets cautiously (Hava 2015; Périnel 2016). The local government also plays a role in municipal debt. It can regulate the possibilities of the indebtedness of the municipalities. Most countries have a certain system of debt regulation given by the legislation. This can partially prevent debts (see Hornek 2016: 115-116). In spite of a certain regulation of municipal indebtedness, there are municipalities in individual countries in Europe that are deeply in debt. Large municipalities with more than 100,000 inhabitants have the largest debts in Italy ${ }^{31}$ and Poland. ${ }^{32}$ By contrast, small municipalities with up to 5,000 inhabitants have the largest debts per capita in countries such as the Czech Republic, Austria, ${ }^{33}$ Slovenia $^{34}$ or Hungary. ${ }^{35}$ Slovakia is an example of a country where the most indebted cities have over 10,000 but fewer than 100,000 inhabitants. ${ }^{36}$ Similarly, the most

31 In 2014, the most indebted municipalities were Torino ( $€$ 3,519 per capita), Milan ( $€$ 3,036 per capita), Siena ( $€ 2,457$ per capita) and Genoa ( $€ 2,172$ per capita). It has been attempted to deal with the indebtedness by requesting funding from the state, increasing the municipal tax and lowering the municipal waste and public transport rate, and by providing fewer public services (Secolo d' Italia 2014).

32 In 2015, Bydgoszcz, Płock, Łódź and Toruń had the highest ratio of debt to the total annual income of municipalities. The ratio reached $95.34 \%$ of annual income (Fakt24.pl 2015; Sąsiada 2015; WP finance 2016).

33 Austrian municipalities that have been indebted for a long time have fewer than 1,000 inhabitants. Debt per capita exceeds 10,000 € per capita. This high debt is most common in Vorarlberg. Examples are Dünserberg (debt per capita $€ 13,084)$; Warth (€ 14,869), Schröcken (€ 24,696), Damüls $(€ 10,472)$, St. Gerold (€ 13,992), Klösterle (€ 11,287) (Burth 2015; Meinbezir.at 2015; Statistik.at 2016).

34 The most indebted municipality of Slovenia, Gornji Petrovci (2,057 inhabitants), had a debt per capita of around $€ 1,740$ in 2013. The second most indebted municipality was Solčava and its debt per capita was $€ 1,334$. By contrast, Ljubljana had the highest total debt of EUR 171 million (624 per capita). Slovenian municipalities are generally under-financed; since 2011 they have received lower budget transfers than they are legally entitled to. Small municipalities have to provide the same services as the large ones, which poses a problem. For example, all 212 municipalities have to provide services such as day-care for pre-school children, primary school, primary healthcare or social services. In order to cut their costs, municipalities often form joint municipal administrations, which carry out certain tasks for multiple municipalities. (Slovenia News 2018; Sobotainfo.com 2013)

35 The situation in Hungary is similar to that in the Czech Republic since the most indebted municipalities are those that had a failed investment project.

36 The most indebted cities in Slovakia are municipalities with over 10,000 inhabitants. An example is Žilina. The municipality owed $59.7 \%$ of its current revenue (debt of $€ 349$ per capita) in 2015, which after many years fulfilled the statutory criteria. Other examples include the city Púchov ( $€ 307$ per capita) and Čadná ( $€ 232$ per capita). Žilina had the worst financial situation for years. The state had to help by waiving the debt in the amount of $€ 5,840,000$ (Vláda SR 2014; Tunega 2015; Čas.sk 2015). 
indebted cities in France have over 20,000 inhabitants and in Portugal over 55,000 inhabitants. ${ }^{37}$ States like Germany ${ }^{38}$ and Spain ${ }^{39}$ have a very high debt in both large municipalities over 100,000 and in small municipalities under 5,000 inhabitants.

The critical debt of the municipality is becoming a major topic of local politics. It is the main problem that the representatives of the municipality must solve. The issue of dealing with the critical debt is a major topic of municipal elections and even of election campaigns. In extreme cases, local residents might not even want to run in the municipal elections and lead the community. It can be expected that the elected positions in indebted large municipalities are still appealing to the candidates despite their indebtedness. However, in the case of small municipalities, where the attractiveness of the elected positions is less even under regular conditions, the debt increases the potential lack of interest in leading such a municipality. In larger municipalities, the political parties can be expected to find different solutions to the problem with debt and the population would also have different opinions on what approach is the most reasonable. On the contrary, there may be a consensus in small municipalities, even though it is not a rule. The residents are aware of the debt due to the consequential reduction in services provided. In this case, the size of the municipality does not matter, since services are limited both by small and large municipalities. On the other hand, large municipalities cut down on above-the-standard services, while small municipalities have to reduce even the most basic ones. Large municipalities have more redundancies, the municipal property is sold, and fees for transportation and local taxes are increased. Critical debt can lead to people leaving their residence, which is a problem, especially for small municipalities. With long-term debt of large municipalities and the migration of a high proportion of the population, the number of elected representatives is decreasing, as in the case of the phenomenon of shrinking municipalities.

37 For example, Levallois-Perret $(€ 9,129$ debt per capita) has a total debt of $€ 595$ million (Bourquard 2015). In recent years, the worst situation in Portugal has been experienced by the town of Portimão $(55,614$ inh.), which had its accounts frozen for three years. It could not invest and in general manage its municipality because its debt amounted to 162 million euros. The municipality began to drastically reduce and lay off its workers. In 2016, it received a loan worth $€ 142.5$ million from the Portuguese Municipal Fund, to be repaid by the city within 27 years (Portugal News 2016).

38 The most indebted large cities are located in the Ruhr area. These are municipalities such as Oberhausen, Duisburg, Hagen, Herne and Mülheim an der Ruhr (Mittermeir 2015). The smallest municipality in Germany Gröde with nine inhabitants has the largest debt per capita of ( $€ 26,767$ per capita). Other examples are a small municipality of Putgarten ( $€ 19,357$ per capita), Langeness ( $€ 19,086$ per capita) and Damp with fewer than 1,500 inhabitants ( $€ 21,633$ per capita) (Wetter 2014).

39 A frequent cause of large debt in Spanish municipalities is the consequence of the 2008 economic crisis, which is also connected with the collapse of construction (Gonzáles 2013). The municipalities in trouble are located in Andalusia and Valencia (Fernández 2013). One of the most affected Spanish municipalities is, for example, Jerez de la Frontera, which has more than 200,000 inhabitants and is one of the most indebted municipalities. In 2013, each inhabitant owed $€ 4,600$ (Al Jazeera 2013). 
Based on empirical examples, five possible situations which can occur in a critically indebted municipality have been identified:

1. An unresolved situation;

2. A bankruptcy of the municipality;

3. A temporary assumption of management of the municipality;

4. Financial aid from the state;

5. Municipalities solve their debts themselves.

1. An unresolved situation. The first possible situation was described in the introduction and exemplified by the Czech municipality of Prameny. It represents one of the worst situations that can be encountered in Europe. The municipal debt is deepening and the situation has to be dealt with ad hoc by the state. The same situation is in the Czech municipality of Turovice (219 inh.); however, the total debt is lower (3,12 million euro in 2017). Spanish Pioz with 3,600 inhabitants is in a similar situation to Prameny. Pioz has been indebted because of developers' projects. At the current installments of $€ 2,000$, the debt would be repaid over the next 7,000 years. The municipality is unable to pay for everyday activities, such as public lighting or garbage disposal, and road maintenance has been stopped. There is also a $25 \%$ unemployment rate in the municipality due to the debt (Govan 2012). At present, the worst situation is apparently faced by the Slovak municipality of Ondavka, which is critically indebted despite the fact that the total debt exceeds 'only' more than 30,000 euros. The municipality has only 15 inhabitants. Ondavka was indebted under a former mayor who was found guilty of violating his obligation in the management of foreign property. Still, he won the election in 2006, and in 2012 he resigned. Ondavka, under the leadership of a former mayor, did not even initiate the recovery regime it had been ordered to undertake. The municipality faces ten executions, the public lighting is not lit, the garbage is not taken away, and the inhabitants have not paid local taxes and fees for years. Since January 2015 , nobody has run the municipality. The last seven elections for the mayor and deputies have not been held. Nobody takes an interest in running for the elected positions. The situation can only be solved through the amalgamation with the surrounding municipality, which should receive state aid for the amalgamation. (Otriová 2017; Tvnoviny.sk 2018)

2. A bankruptcy of the municipality. The second possibility is the bankruptcy of the municipality. Unlike in the US, this is virtually absent in Europe. A unique example is the Swiss municipality of Leukerbad (1,600 inhabitants). Since the 1990 s, the municipality has been massively investing in spas, services and local infrastructure, bringing its total debt up to 350 million CHF, approximately 219 thousand francs per capita. The village was unable to repay its liabilities. For more than 15 years, it had no money and was not repaying its debt. Canton Wallis was expected to help, but that did not happen. The municipality fell 
under forced administration. The representatives of the municipality had to sell all the property as well as the town hall. Even the other municipalities in the vicinity of Leukerbad had to sharply reduce their expenses. Therefore, the solution was the bankruptcy of the municipality. Leukerbad has been suffering the consequences to this day, constantly saving drastically. But it benefits from its location in the mountains and from the interest of tourists. The municipality is committed to repaying 1.3 million Swiss francs each year. The mayor admitted that it was surprising that the debt had not affected the main revenues of the municipality, which is also the reason it survived the bankruptcy. There is minimal unemployment in the municipality, its inhabitants have not left and population growth is stable. Leukerbad is even more attractive to new residents because it has a school and a pre-school in the area. On the other hand, local taxes are at the highest possible limit. (Teevs 2013) As can be seen from this example, the bankruptcy of a municipality does not have to lead to its failure. On the contrary, it is more about restarting and ending paralysis and thus slowly beginning with new development.

\section{A temporary assumption of management of the municipality. Most Eu-} ropean countries are not allowed to bankrupt their municipalities. However, municipalities may be placed under forced administration; an example of this would be Slovakia. In 2015, nine municipalities were under forced administration in Slovakia. In 2017, the number decreased to five municipalities: Devín (1,538 inh.), Luhyňa (304 inh.), Švedlár (2,145 inh.), Ladomirová (1,055 inh.) and the city of Martin (54,978 inh.). Municipalities under forced administration cannot invest in any way, develop or apply for subsidies. They can only lead the municipality in the most basic way, such as road maintenance or pay for municipality employees. Therefore, in the case of municipal development, local citizens set up civic associations to address municipal problems (Krčmárik 2015; Liptáková 2017). In Poland, the management is temporarily given to a commissioner. In these municipalities, all services are cut and all the money is used for debt repayment. The spiral of debt in Poland often consists of the government repeatedly imposing new obligations on municipalities without raising the money for this purpose. Therefore, municipalities have to borrow money to fulfill the requirements of the government. The banks lend the money even to the municipalities with large debts. It is certain that they will get their money back because it is a state debt. So far, there is no law prohibiting the banks in lending money to the municipalities in poor condition (Skrobisz 2015). For example, in Germany the position of a 'Sparkommissar' helps the municipalities in financial problems. One is either appointed by the supervising ministry of the interior or through an agreement between the ministry and the municipality. Municipalities such as Waltop (2005) and Nideggen (2014/2015) have had experience with this institute (Kimmel 2006; Welt.de 2013). 
4. Financial aid from the state. In some countries, the municipal debt is taken over by the state and (partly) repaid. Such situations have appeared in Hungary, Slovakia and the Czech Republic. For example, in Hungary in 2013, the state paid $80 \%$ of the total debt for 14 municipalities. These included the Harkans with a debt of $€ 14.9$ million (3,889 per capita), of which the state has taken over $€ 10.32$ million. Other examples are Bükkszék and Balatonfüzfő (each total debt is around $€ 3.2$ million). The state helps because municipalities have to fulfill the basic functions, even if they do not have the finances to do so (Válasz.hu 2013). More than a decade ago in the Czech Republic, the state first bought back hundreds of millions of debts of the town Rokytnice nad Jizerou, and the city was gradually and quite substantially waived of its debts (Hornek 2016). An example in Slovakia is the city of Žilina, and a probable candidate is Devín, as it faces a very bad situation. In 1997, there was the intention to build a residential neighborhood, which failed thus resulting in its current indebtedness. The municipal debt is virtually unpayable since the interest alone represents essentially the annual income of the municipality, which has sold everything. Devín has been under forced administration since 2005. Devín's debts exceed 10 million euros and the municipality is unable to get out of this situation alone. The only options are a change in the legislation and the possibility of bankruptcy of municipalities or assistance from the state or from the Bratislava City Hall, as Devín is one of Bratislava's main districts (Krčmárik 2015; Ineko 2016; Liptáková 2017).

5. Municipalities solve their debts themselves. The municipalities in this category deal with debt on their own. The majority of European indebted municipalities fall into this category. Depending on the extent of the debt, there is a reduction in services; possibly, an increase in local fees (taxes) and financial problems are becoming the subject of local politics. In this category, there are all possible sizes of municipalities. One example may be the German city of Oberhausen, which is one of the most indebted municipalities. In 2013, it was the most indebted city and by 2015 each of more than 210,000 inhabitants owed 9,450 euros. In addition to the closure of the heavy industry and the associated consequences, the city also financially contributed to the solidarity tax when the West German municipalities financially supported the municipalities in the former East Germany. Several austerity measures were in place in the city. For example, the swimming pool, several schools and libraries were closed down and local parks were not maintained. On the contrary, the city is trying to financially support cultural events and has not closed down local theatre, which costs up to $€ 8$ million a year, because cultural events attract young people who should be the future for the city (Eddy 2013; Mittermeir 2015). The possible situations are not mutually exclusive. A municipality may go over several phases at one time, depending on the local legislation and the possible means that can be used for debt relief. 


\section{Demographic threats to municipalities}

Demographic threats to municipalities include, in particular, the phenomenon of shrinking municipalities (e.g. Bart 2011), when municipalities lose their inhabitants for a variety of reasons. The phenomenon affects municipalities across size groups (ed. Oswald 2006). The scientific community addresses the issue to a great extent. These are municipalities ${ }^{40}$ that lose up to tens of percent of their inhabitants, which poses significant problems for them. Efforts to remedy and stop inhabitants from leaving are one of the main goals of the municipality. On the other hand, such threats in larger municipalities do not pose a direct endangerment to the extinction of the municipality. The direct threats connected to demographic problems of municipalities are mainly perceived in the smallest municipalities that are most at risk. For this reason, we primarily focus on the smallest municipalities with fewer than 50 inhabitants..$^{41}$ These municipalities do not represent the phenomenon of shrinking municipalities, but rather the very fact of a low number of population, augmented by the high average age of the local population, low birth rates, higher mortality and unattractiveness of living in the municipality.

Very small municipalities can be found mainly in the countries with a higher number of municipalities. What is quite typical of such states is in general a high percentage of municipalities with fewer than 5,000 inhabitants. More than $85 \%$ of municipalities with fewer than 5,000 inhabitants can be found in the Czech Republic (96\%), France, Slovakia (95\%), Hungary (91\%), Austria (91\%), Switzerland (89\%) and Spain (85\%). On the contrary, Poland has $25 \%$ of such municipalities and Romania 35\% (Baldersheim - Rose 2010: 3; Eurostat 2017). Municipalities with up to 50 inhabitants can be found particularly in France, Spain, the Czech Republic, Slovakia, Switzerland or in Germany. ${ }^{42}$

The smallest municipalities have, in the vast majority of cases, low budgets and do not provide too many services to citizens. There are not enough job of-

40 For example, let us mention Marseille (it lost 116 thousand inhabitants in the years 1975-1999), Genoa (it lost 226 thousand inhabitants in 1970-2000), Düsseldorf (it lost 116 thousand inhabitants in 1960-2000) or Chemnitz (it lost 55 thousand inhabitants in 1980-2000) (ed. Oswald 2006).

41 The stated number of population cannot be taken strictly because similar problems are often found in municipalities with several hundred inhabitants.

42 It is necessary to add: In Spain, 1,238 municipalities have fewer than 101 inhabitants (INE 2016; Gosálvez). In the Czech Republic in 2017 there were 453 municipalities with 100 or fewer inhabitants. Sixty-six municipalities even have 50 or fewer inhabitants and $55 \%$ of all municipalities have fewer than 500 inhabitants (ČSú 2017). In Slovakia in 2017 there were 137 municipalities with fewer than 100 inhabitants and 991 municipalities with 100 to 499 inhabitants (Statistical Office 2017). In Switzerland there are 33 municipalities with fewer than 100 inhabitants and a total of 401 municipalities with fewer than 500 inhabitants (Statistik Schweiz 2018). In France in 2015, there were 3,541 municipalities with 100 or fewer inhabitants and a range of 101-500 inhabitants could be found in France in 16,223 municipalities (INSEE 2016). One hundred of the smallest German municipalities with fewer than 70 inhabitants can be found mainly in three Länder - Rheinland-Pfalz (72 municipalities), Schleswig-Holstein (23 municipalities) and Thüringen (5 municipalities) (Destatis 2016). 
fers in the municipalities, so the residents have to commute to work or school. Another typical feature is worse traffic servicing. In the smallest municipalities, there is also a minimal variability in the candidacy to municipal councils. Often, the same candidates stand in the elections and the leadership of the municipality does not have to change throughout many election periods. The smallest municipalities often lack any classic political competition, as the inhabitants know each other very well and can even have close to 'family' relationships. Possible situations in the smallest municipalities have been divided into the following four possible scenarios that we will outline:

1. The municipality is about to cease;

2. Preserved situation;

3. Municipalities decide to merge;

4. Development of the municipality.

1. The municipality is about to cease. This is a situation where municipalities are heading towards their extinction or merging with neighboring municipalities. This includes the smallest municipalities with only a few inhabitants and with no means of gaining new inhabitants. In such municipalities, there is a high average age and the same long-term leadership of the municipality. The municipality gets into this situation on the basis of an active cause. Examples may be as follows:

a) the lack of interest of the local population to stand in the elections (the inhabitants are often persuaded to run but do not do so even though they wish to preserve the independence of their municipality);

b) rapid population decline;

c) critical indebtedness; or

d) legislative changes leading to the extinction of municipalities.

The general problems of the smallest municipalities are further exacerbated by these causes. If the situation is not solved, the municipality finds itself in agony.

An example is the Slovak municipality of Jurkova Vola with 79 inhabitants. The leadership of the municipality decided not to stand in the elections and the other inhabitants were not interested in standing as candidates. Since April 2018 there has been a possible solution to such situations in Slovakia. The municipality where municipal elections have failed two times in a row may integrate with a neighboring municipality in the same district (TVnoviny.sk 2018). This is probably the way similar problems will be treated in Slovakia. This is how the above-mentioned situation regarding indebted municipality of Ondavka will probably be solved. Another example is the smallest Swiss municipality of Corippo with 13 inhabitants, which has been run by the municipality administrator since this year, as the mayor resigned after more than 20 years and no candidate is interested in running for the office. There have already been two quests for amalgamation, though they were not favoured by most of 
the neighboring municipalities. A third attempt to gain support for Corippo amalgamation is being planned (Schweizer Bauer 2018). Other examples of the decline in the population can include the Czech municipalities of Čilá and Vysoká Lhota, where it has been possible to draw up a candidate list so far (there has always been the same number of candidates as elected councilors) and the elections do take place, but gradually the two smallest municipalities in the Czech Republic regularly experience a declining number of inhabitants. In 2018, both municipalities had 15 inhabitants, but in 2015 they both had 17 inhabitants, and 22 inhabitants in 2010.

2. Preserved situation. The second situation does not substantially differ from the first, except that the current state is so-called 'preserved' and can last many decades. In other words, the preserved situation does not currently lead to the downfall of the municipality, but in the case of not increasing the number of inhabitants or occurrence of one of the causes of the previous situation, the municipality gets into the first most critical situation.

The inhabitants are reconciled with the functions of their municipality, they do not need to increase or develop their municipality. These are mainly indigenes who have bonded with the municipality and have lived there most of their lives. In the case of leadership and candidacy for these municipalities, the same characteristics apply as in the first case, above all the same long-term leadership and a small plurality of candidates. Examples of these municipalities may include the smallest French municipalities, where it is not possible to expect any amalgamation any time soon. In France, it is possible that within inhabitants there are secondary residents who pay local taxes and are registered in the electoral rolls (Mongaillard 2013). This is why we can come across municipalities that are independent and have fewer than ten inhabitants. We can use as examples the smallest French municipalities, such as Rochefourchat, which has a single permanent resident but its own mayor and a nine-member municipal council, and a municipality of Leménil-Mitry with three inhabitants and Rouvroy-Ripont with seven inhabitants. (INSEE 2016) A large number of the smallest European municipalities find themselves in such a preserved situation.

3. Municipalities decide to merge. A situation where municipalities decide to merge to prevent their actual extinction or to have the opportunity to better develop their part of the municipality. It can happen either under pressure or under motivation of the state or by individual decisions of municipalities. As an example of motivation, Spain offers financial incentives for merging of municipalities; yet, since 1981 only two mergers have taken place. Both mergers took place only because the municipalities had an absolute majority of the same party in their leadership - Partido Popular (Hermida 2013; Reinero 2016). The last amalgamation took place between 2013-2015, and on the contrary six new 
municipalities emerged. In 2014, Spain had 6,813 municipalities with fewer than 5,000 inhabitants (i.e. $83.9 \%$ out of 8,117 of all the municipalities) that qualified for amalgamations of municipalities (Gomez 2015; Gosálvez 2015). A real amalgamation in practice can be found, for example, in Switzerland where it is constantly being carried out. In 2000, Switzerland had 2,899 municipalities, in 2017 only 2,255 and in 2018 the number of municipalities even decreased by 33 municipalities (Statistik Schweiz 2018). Individual cases of merging municipalities are a long-term process, which takes several years to complete. The merging process is supervised and performed by the Gemeindeamt of the canton concerned. For example, most amalgamations took place in the cantons of Ticino, Graubünden, Luzern or Bern. Amalgamation of municipalities is voluntary in Switzerland with some exceptions, ${ }^{43}$ and thus all actors involved must approve of it (Berner Zeitung 2014 Gulde, Locher 2015).

4. Development of the municipality. Rather a theoretical situation is the possible development of the municipality, which will lead to the arrival of new inhabitants or to a higher birth rate, which would revert the local situation. Such a situation rarely occurs in the smallest municipalities because those communities can hardly afford their development. They would first have to secure finances and make a successful investment project that would make the municipality more attractive. In case of failure, there is a risk of critical indebtedness and the cases we know, for example, from the Czech Republic or Spain.

The above-mentioned four possible situations can in principle also be applied to the municipalities with several hundred inhabitants. They do not have to face imminent endangerment, yet all of the characteristics described can concern them, possibly with one exception that they may not be so fatal for these municipalities.

\section{Endangered by natural and environmental disasters}

Natural disasters and environmental disaster can inherently pose a danger to any municipality. In this case, it is important in what area the municipality is located ${ }^{44}$ rather than the size of the municipality. The size of the municipality itself can, however, play a role in dealing with a disaster. By nature, small municipalities can be more vulnerable in prevention and handling of the disaster

43 An example of a voluntary amalgamation could be the municipality of Bettmeralp (439 inhabitants), which was formed (2014) from the merger between Martisberg and Betten (canton of Valais) (Berner Zeitung 2014). An example of the extraordinary forced merger is the former municipality of Ausserbinn (41 inh.), which had to integrate with the municipality of Ernen in 2004, following the decision of the parliament of the canton of Valais. The municipality even addressed the courts, but unsuccessfully (Gulde, Locher 2015).

44 Whether extreme forms of natural processes or the potential threat of environmental disaster can be expected in their vicinity. 
than large cities, for example, because they do not have such large budgets or usually lack the organs of a rescue system or other services. ${ }^{45}$

It is often complicated to determine in a variety of disasters when and where they will break out. Their impacts on the municipalities vary. Many natural disasters may be impending in many places, such as floods, which may strike in the watershed of various European rivers and streams. It is the floods that we meet in Europe at certain intensities every year. Let us be more specific in localizing threats in the case of earthquakes. On the basis of the research from the SHARE project, such areas/countries were defined where hazard runs high, i.e. $10 \%$ probability and higher that within fifty years an earthquake will hit. These are Italy, Greece, the Balkan countries, Bulgaria, Romania, Turkey and Iceland. (Du Brulle 2014) As regards the threat of volcanic activity, it is possible to speak of specific places, with the three most dangerous volcanoes in Europe being Etna, and Vesuvius in Italy and Mount Teide on the island of Tenerife. ${ }^{46}$ There are also active volcanoes in the Portuguese Azores and Madeira, and there are six active volcanoes in Greece. Volcanic activity also threatens Iceland, where four volcanoes have been active in the recent past. ${ }^{47}$ (Smithsonian Institution 2016, Volcano Discovery 2016). In the case of threats from environmental disasters, European municipalities that have strategic industries, nuclear power plants and similar objects located in their cadastral area or vicinity are potentially at risk.

If the municipality has been affected by some of the above-mentioned disasters, the rescue of life and property are the first to be addressed. At the time of the disaster, the municipality is run by the current leadership and it is up to it to decide how to cope with the situation and how to cooperate with the higher territorial units and components of the state. According to Kingdon (1984), a natural disaster provides an opportunity for political action. Public

45 This may not always be the case, especially in the locations where natural or environmental disasters can be expected or already affected the municipality in the past. The similar applies even if municipalities have, for example, chemical plants, nuclear power plants and the like in their area or in their vicinity. The fact that the small municipality is 'sufficiently' safeguarded for a possible disaster is often given by the financial help from a higher territorial unit or state, since smaller municipalities can hardly afford such securitisation, or possibly at the cost of a loan or subsidy.

46 Etna is the highest and most active volcano in Europe, which was last active in 2011. The most endangered cities are primarily nearby Messina and Catania. Vesuvius is very dangerous, not only because nearly three million people live near it, but also because it was last active in 1944. In the Canary Islands in Spain, there are eight active volcanoes. For example, the following municipalities are near these volcanoes: Tuineje, Frontera, Gáldar, Artenara, Alajeró, Santa Cruz de la Palma, Tinajo and La Orotava.

47 The following municipalities are potentially most at risk in the Azores: Vila do Corvo, Vila Franca do Campo, Ponta Delgada, Povoação, Santa Cruz da Graciosa, São Roque do Pico, Velas, Angra do Heroísmo and on the island of Madeira the municipality of Ribeira Brava. In the vicinity of the Greek volcanoes there are, for example, the municipalities of Agioi Theodoroi, Santorini, Nisyros, Milos and Troizinia-Methana. In Iceland the following volcanoes were active in the past - Hekla, Bárðarbunga, Eyjafjallajökull and Grímsvötn, with the following municipalities in close vicinity - Mýrdalshreppur and Bláskógabyggð. In Iceland, we should rather speak of threats to individual settlements (e.g. Hella, Stóri Núpur, Ásolfsskälli etc.) than entire municipalities, as the municipalities of Iceland have a cadastral area of up to several thousand square kilometers. 
officials can use a natural disaster to demonstrate their leadership abilities and willingness to solve difficult problems. The role of the political leadership of responsible representatives of the municipality plays an important role. Studies show that if voters perceive that politicians are responding badly to disasters, they lose considerable votes in the elections (Brancati 2007). If the political impacts on local politics are reflected, then it is only after some time, depending on the damage incurred to the municipality and whether the existing leadership handled the situation well. For example, people in affected municipalities may be expected to prepare preventions against a repeated threat (for example in case of floods) in the future. For this reason, the theme of the disaster (whether a past one or a future one) will considerably resonate in local politics. The experience with a disaster is likely to affect the decision-making of the councilors, the direction of the municipal finances and the development of the municipality. The political impacts will also be linked to the subsequent reactions in the socio-economic spheres when unemployment is rising, the psyche of the population is deteriorating and entrepreneurs are going bankrupt. As a consequence of disasters, there are expenditures from the state treasury in the vast majority of cases; it has to finance and pay the consequences, which burdens the budget of the whole state (Hladný 2007: 41). In response to these impacts, residents can also decide that they no longer want to live in such a municipality and leave it.

Natural and environmental disasters can have a wide variety of impacts on the municipality, ranging from the absence of any (political) intervention in the municipality to its possible extinction. The situation is always specific and the impacts are individual. Still, four model situations have been created of what impacts can occur in municipalities:

1. Extinction of the municipality;

2. Long-term restoration of the municipality;

3. Partial influence on the running of the municipality;

4. Not affecting the municipality.

1. Extinction of the municipality. The impact of the disaster is so pronounced that the municipality's extinction is decided for over its renewal. A decision may involve establishing a new municipality or relocating residents to other municipalities.

For example, let us mention the town of Prypjat, evacuated after explosion in the Chernobyl nuclear power plant, which is still a forbidden uninhabited zone. After the disaster, a new city of Slavutych ${ }^{48}$ was built for the inhabitants of Prypjat, where around 25,000 inhabitants lived in 2014, (i.e. since 1989, the population increased by 14,000 inhabitants) (ed. Oswallt 2006). This category

48 In 2011, the average salary in the city was almost double that of the state average and the average age was only 32 years. (ed. Oswallt 2006) 
also includes an example of the United Kingdom's overseas territory, Montserrat Island. The capital city of Montserrat, Plymouth with four thousand inhabitants, had to be abandoned in 1997 after volcanic activity. Two thirds of the island were evacuated, most of the evacuated population did not return to the island. The destruction of the city meant serious economic problems for the whole island. On the island, among other things, it was necessary to rebuild all the institutions that were based in the capital city (BBC news 2005).

2. Long-term restoration of the municipality. In this scenario, the municipalities are heavily damaged by a natural or environmental disaster; therefore, reconstruction is long-term and lasts many years. In this scenario, municipalities are heavily affected by natural or environmental disasters, and therefore reconstruction is long-term and lasts many years. Gradually, as is possible, residents return to the municipality. ${ }^{49}$ There can hardly be any talk about the classic local politics and the everyday functioning of the municipality, the elections are not held at all or are not held in due time. As a result of differences in practice in individual states, the state may be expected to assume the role of coordinator, the representatives of the affected municipality act and cooperate with state authorities, without whom it would be difficult for the municipality to recover.

Italian municipalities that have been hit hard by earthquakes include L,Aquila (2009) and Amatrice (2016). The state spent more than nine billion euros on the reconstruction of the city, and yet L,Aquila is not entirely restored. The inhabitants still do not want to return from the suburbs and the surrounding new small villages back to the centre of L,Aquila, where everything is still being reconstructed. It is expected that no earlier than 2019 will the city centre be restored (Du Brulle 2014; Radačičová 2016). On the other hand, big damage to municipalities does not necessarily have to lead to their extinction, but on the contrary to new construction and hence the impetus of new development. ${ }^{50}$

3. Partial influence on the running of the municipality. In these cases, this is not a many-year-long reconstruction as in the previous model as only part of the municipality may be affected. For some time, running of the municipality and the services provided are provisory, but the organs still carry on their work in a certain way.

As examples, let us mention the Czech municipalities of Lukavec (380 inhabitants), Keblice (365 inhabitants) and Račice (314 inhabitants) affected

49 For example, when Hurricane Katrina hit New Orleans, the town lost $72 \%$ of its inhabitants between August of 2005 and April of 2006 (ed. Oswald 2006: 62).

50 An example is Japanese Kobe, which, after a severe earthquake of 6.9 on the Richter scale in 1995, had more than 180,000 buildings damaged or destroyed and vastly destroyed infrastructure. Kobe, however, was quickly restored beyond expectations and became the inspiration for more resilient buildings and other cities (Alexander 2012; Radačičová 2016). 
by the floods in the summer of 2002. The inhabitants of these municipalities failed to submit candidate lists to municipal elections within a set deadline because they were primarily preoccupied with the consequences of the floods. Therefore, the elections were not held in the municipalities in November 2002 in due time. The municipalities thus had to be run by the administrators of the municipalities until the end of March 2003, when the new elections took place $^{51}$ (Milerová 2016).

4. Not affecting the municipality. The disaster did not seriously endanger the running of the municipality in any aspects. Thus, municipalities can provide their citizens with the same amount of services and at the same quality. Municipalities are able to cope with small consequences of the disaster themselves. Even in the political life of the municipality, the disaster does not affect the political competition or the participation. Local elections take place in due time. Municipal protection and preparation for future disasters can become a pre-election issue.

Examples are the Czech municipalities of Nový Oldřichov, Volfartice and Horní Libchava (the Liberec region), hit by the floods in July 2009. However, the municipalities handled the situation themselves and the impact of the floods was not significant (Ministry of the Environment of the Czech Republic 2009: 17).

\section{Less common threats to municipalities}

\section{Threats by higher intent}

The term 'threat by higher intent' refers to a decision by the state or the region that the municipality will surrender its needs to the greater social needs. This is often contradictory to the opinion of the local population that has to submit to the decision. They are relocated and the municipality ceases to exist. The pursuit of reversing the higher intent tends to be a major political issue. In these cases, the local situation is subject to the local nationwide media interest and the views on the possible extinction of the municipality are also expressed by the highest political representatives. Residents of the affected municipality may also be motivated by the state (through financial or other compensation) to consent to the extinction of the municipality. The term a higher intent may refer to the construction of strategic building $\mathrm{s}^{52}$ in the area where the municipality is,

51 The impacts of the floods in the additional municipal elections in these small municipalities did not lead to a consensus across the municipality and one joint candidate list. On the contrary, there were more candidate lists in all the municipalities and a higher plurality of candidates.

52 These can be, for example, dam constructions, nuclear power plants, or airports. A specific example is the attempt to build a third start-up runway at the Munich Airport, which should be located in Attaching, which has been part of the Freising municipality since 1978. Local residents are against its construction. 
or the mining..$^{53}$ There are basically only three alternatives: a) the proponents of the municipality persuade the neighborhood/state that it should continue to exist and the intent is not realised; b) the realisation will occur and the municipality will yield to a higher intent and will cease to exist, the inhabitants will be relocated; and c) a compromise alternative occurs, when only part of the municipality becomes extinct and the rest of the municipality remains and continues to function.

\section{Threats from military conflict}

\section{Fortunately, there is currently no threat of warfare in the studied European} countries. However, it was possible to observe this in Europe in the recent wars in former Yugoslavia ${ }^{54}$ or in the current conflict in Eastern Ukraine. In case of threat by warfare, as well as by environmental disasters, the main concern lies with the lives of the population; however, a military conflict affects all public affairs. This means that it also affects the functioning of municipal self-government. It is then marginalised and the municipalities stop functioning in the affected areas as a result of the intensity of the conflict. Such situations may occur when municipalities are destroyed completely due to the war conflicts. ${ }^{55}$

The main political activity in Attaching concerns this construction (Attaching 2017). Another example is the fate of a part of the municipality of Kursdorf (part of the city of Schkeuditz), which formally exists but nobody lives there any more due to the immediate proximity to the airport in Leipzig/Halle (Kursdorf 2009). For example, due to a higher intent, a number of municipalities disappeared in the past in the Czech and Slovak territory. Examples include the municipality of Chudobín (destroyed in 1950-1960 due to the construction of the Vír water reservoir), the municipality of Mochovce (the Slovak municipality was destroyed in the 1980s and the inhabitants were relocated due to the construction of the Mochovce nuclear power plant; formally the municipality was amalgamated with the neighboring municipality of Kalná nad Hronom) or the municipality of Kundratice (the municipality was completely destroyed due to brown coal mining in 1974) (Extinct Municipalities 2018).

53 So far, the last municipality in the Czech Republic destroyed due to coal mining was the municipality of Libkovice in 1993, despite the persistent resistance of the inhabitants of the municipality and their blockade with their own bodies. However, there has long been a discussion about the possible dissolution of the town of Horní Jiřetín (2,237 inh.), endorsed, for example, by President M. Zeman. The neighboring municipality of Dolní Jiřetín was swallowed by coal mining in 1983 (Baroch 2013).

54 An example may be the town of Mostar (Bosnia-Herzegovina). About 40,000 inhabitants left before 1995 and $70 \%$ of the houses were destroyed or damaged. After the war, the city was divided into two nationally separate groups. A consequence of the war was the destruction of the traditional industry, the rise in unemployment and the departure of young and educated people, which made it difficult to develop the city (ed. Oswallt 2006).

55 Six French municipalities could serve as an example (Beaumont-en-Verdunois, Bezonvaux, Cumières-le-Mort-Homme, Fleury-devant-Douaumont, Haumont-près-Samogneux, Louvemont-Côte-du-Poivre) that were destroyed during the Battle of Verdun in 1916. It was decided that they would neither be restored nor integrated with other municipalities. The stated ghost communes legally do exist, but are not populated at all and are managed by a council of three members, appointed by the prefect of the Meuse département. The reason is to maintain the testimony of the municipalities that had died for France (Roads 2015). An example from the Second World War can be the exterminated Czech village of Ležáky, which was burned down and its inhabitants murdered in June 1942 as a result of the Heydrichiad; it was not subsequently restored. The same fate awaited the municipality of Lidice only 14 
Once the conflicts are over, the affected municipalities are primarily concerned with the attempt to gradually restore the functionality of the municipality and its actual restoration. As a result of war conflicts, the phenomenon of shrinking municipalities is very often manifested in municipalities (eds. Oswallt 2006). The same model situation applied to a threat by natural or environmental disasters can basically be used for the threat by a war conflict. An important difference in this threat is that overall state aid for the regeneration of municipalities will depend on the overall intensity and length of affliction in the whole country. There is also the possibility of international assistance in the rebuilding of the country/municipality.

\section{Conclusion}

Do the examined threats in fact lead to the extinction of European municipalities? Not really, there are not many municipalities nowadays that would become extinct because of endangerment by one of the identified threats. If municipalities do become extinct, it is mainly because of the decision of small European municipalities to merge with each other and create one common municipality. These processes are currently observed in Switzerland, for example. Generally speaking, in the issue of endangerments by a very small number of inhabitants in the municipality, the situation across Europe (especially, for instance, in France, the Czech Republic, Slovakia and Spain) is often conserved; in other words, municipalities seek to preserve their independence and are not interested in amalgamation. They find it sufficient for their municipalities to provide limited services only and they also accept the fact that their municipalities are not able to develop. Assuming that these (smallest) European municipalities do not get new inhabitants in the future, then with the aging of the existing population and the migration of the population to urban areas (in 2018, 74\% of the population of Europe lived in urban areas (UN 2018)), the municipal problems will escalate. In the future, it can be assumed that these problems will have to be addressed, most probably systemically (for example, by consolidation reforms), as they may concern hundreds to thousands of small European municipalities. Another real threat of municipal extinction may be the extinction due to a higher intent or, possibly, upon the effects of a natural-environmental disaster. When threatened by a higher intent, this always involves a specific national situation that leads to the extinction of the municipality in the event of a really higher need for state interest. Natural and environmental disasters can inherently pose a threat to any municipality, regardless of its size. What is significant is

days earlier, but it was restored after the war. A similar fate, for example, affected the French village of Oradour-sur-Glane, which was wiped out and destroyed by German soldiers in 1944. After the war, the ruins of the village were preserved as a reminder of the horrific act and the municipality was restored in the immediate neighborhood. 
the area in which the municipalities are located and whether extreme natural processes or the potential threat of the environmental disaster can be expected in their surrounding areas. Nevertheless, the very affected municipalities are not dissolved and are being restored. In the event of endangerment stemming from critical indebtedness, no municipality has actually become extinct or been merged, also because the new merged municipality would have to assume the debt of a critically indebted municipality. Such a step would require a debt relief or a gain of financial support for the newly emerging municipality, most likely from the state. The Slovak municipality of Ondavka is the closest to experience such a situation and extinction. The last identified threat is only theoretical in today's (western) Europe and, fortunately, not current. Yet, it is a threat that led to the disappearance of a large number of European municipalities in the past.

All of the aforementioned five identified types of endangerment of municipalities were viewed separately. Yet, as can be seen from concrete examples, the causes of endangerment can be interconnected, or they can follow one another and intensify the critical situation in the municipality. Such examples may be, for example, as follows:

a) municipalities with a very small number of inhabitants that are critically indebted due to their attempts to make their municipality more attractive;

b) a heavy debt of large cities can lead to the shrinking of the population, in connection with the possible rising unemployment of the city/region, the limitation of services provided or increasing local taxes;

c) municipalities that have been afflicted by a natural-environmental disaster may, due to the effects of the disaster, become a shrinking municipality because the inhabitants may not want to return after the disaster; or

d) municipalities can become critically indebted in order to settle and recover after a natural-environmental disaster.

Despite the fact that the municipalities do not actually experience extinction, the outlined threats to municipalities can and, in principle, always have some political impact on the afflicted municipality. Political impacts can affect the very form of local democracy. All of the identified threats can bring the municipal politics into a crisis. However, individual impacts always depend on the situation in a particular municipality and the intensity of the threat. It is precisely the diversity of the impacts of individual threats that has shown that the proposed terms of endangered municipality and failed municipality are not alone capable of describing the overall reality of individual municipal situations. For this reason, Table 2 introduces the extension of the terms related to the endangerment of municipalities, which more reflect individual municipal situations. 
Table 2: Terms linked to endangered municipalities

\begin{tabular}{|c|c|c|}
\hline & Term & Characterisation \\
\hline 1. & $\begin{array}{l}\text { Endangered } \\
\text { municipality }\end{array}$ & $\begin{array}{l}\text { A general term that denotes a municipality that may be affected by a particu- } \\
\text { lar threat, which may, in the extreme case, lead to its extinction. }\end{array}$ \\
\hline 2. & $\begin{array}{l}\text { Unstable } \\
\text { municipality }\end{array}$ & $\begin{array}{l}\text { The municipality, which is already troubled by a specific endangerment } \\
\text { affecting the running of the municipality. Elected representatives are aware } \\
\text { of the municipal problem/problems. Because of a serious problem, the muni- } \\
\text { cipality is becoming unstable. As a result of the problem, it can restrict mu- } \\
\text { nicipal services and stop municipal development. At this stage, it is still quite } \\
\text { likely that the municipality will be able to deal with/resolve its endanger- } \\
\text { ment. When solving it, the municipality can try to help itself on its own, but it } \\
\text { is also possible to engage a higher territorial administrative unit or the state. }\end{array}$ \\
\hline 3. & $\begin{array}{l}\text { Paralyzed } \\
\text { municipality }\end{array}$ & $\begin{array}{l}\text { The municipality, which is plagued by significant problems that affect all the } \\
\text { courses of events in the municipality. The municipality has elected leadership } \\
\text { and municipal elections in the municipality do take place. Nevertheless, the } \\
\text { municipal administration faces very limited possibilities how to solve the } \\
\text { municipal situation. There may be no consensus in the leadership of the } \\
\text { municipality about how to cope with the crisis situation in the municipality. } \\
\text { The municipality ceases to provide municipal services and its mission, arising } \\
\text { from the law. In the case of municipal consensus and existing legislation, the } \\
\text { municipality can solve its situation by itself. However, it can be expected that } \\
\text { another entity will be involved in dealing with a crisis situation. }\end{array}$ \\
\hline 4. & $\begin{array}{l}\text { Failed } \\
\text { municipality }\end{array}$ & $\begin{array}{l}\text { It is a municipality that is plagued by very significant problems, which are } \\
\text { even higher than in the case of the paralyzed municipality, as problems are } \\
\text { not solved. In essence, this is the worst possible situation, as the municipality } \\
\text { has set off on the path to extinction. The municipality still exists formally, the } \\
\text { inhabitants do live on its territory, but the municipality does not even fulfill } \\
\text { the most basic functions that arise from the national legislation. In such a } \\
\text { municipality, none of the inhabitants are interested in running for municipal } \\
\text { elections, and therefore the municipality has no elected representatives who } \\
\text { could try to solve the municipal situation. The municipality de facto does not } \\
\text { exist, which results in the fact that it is unable to help itself; consequently, } \\
\text { another entity has to be involved in the solutions. }\end{array}$ \\
\hline 5. & $\begin{array}{l}\text { Extinct } \\
\text { municipality }\end{array}$ & $\begin{array}{l}\text { A no longer existing municipality that has failed to deal with endangerment } \\
\text { and its impacts. The municipality ceases to function and exist, already also } \\
\text { de iure. In connection with the specific situation and the local legislation, the } \\
\text { territory of the extinct municipality is usually integrated/merged with the } \\
\text { neighboring municipality. }\end{array}$ \\
\hline 6. & $\begin{array}{l}\text { Recovering } \\
\text { municipality }\end{array}$ & $\begin{array}{l}\text { The municipality, which has managed to start solving its problems stemming } \\
\text { from the impact of a specific threat. The period of municipal renewal will } \\
\text { vary considerably depending on how deep the crisis occurred in the munici- } \\
\text { pality, i.e. at what stage the recovery process was launched and whether the } \\
\text { municipality solves the situation alone or is assisted by another entity (e.g. a } \\
\text { higher self-governing unit, state or union of municipalities). It can be expec- } \\
\text { ted that the longest recovery will be in the case of failed municipalities and, } \\
\text { on the contrary, the shortest in unstable municipalities. }\end{array}$ \\
\hline
\end{tabular}


Based on the differentiation among these six terms, it was possible to create schemes that reflect possible types of developmental situations of endangerment in European municipalities. The first scheme presents the basic four variants from which four other possible fates of endangered municipalities are derived in Scheme 2.56

\section{Scheme 1: Scheme of possible variants of endangerment}

1.

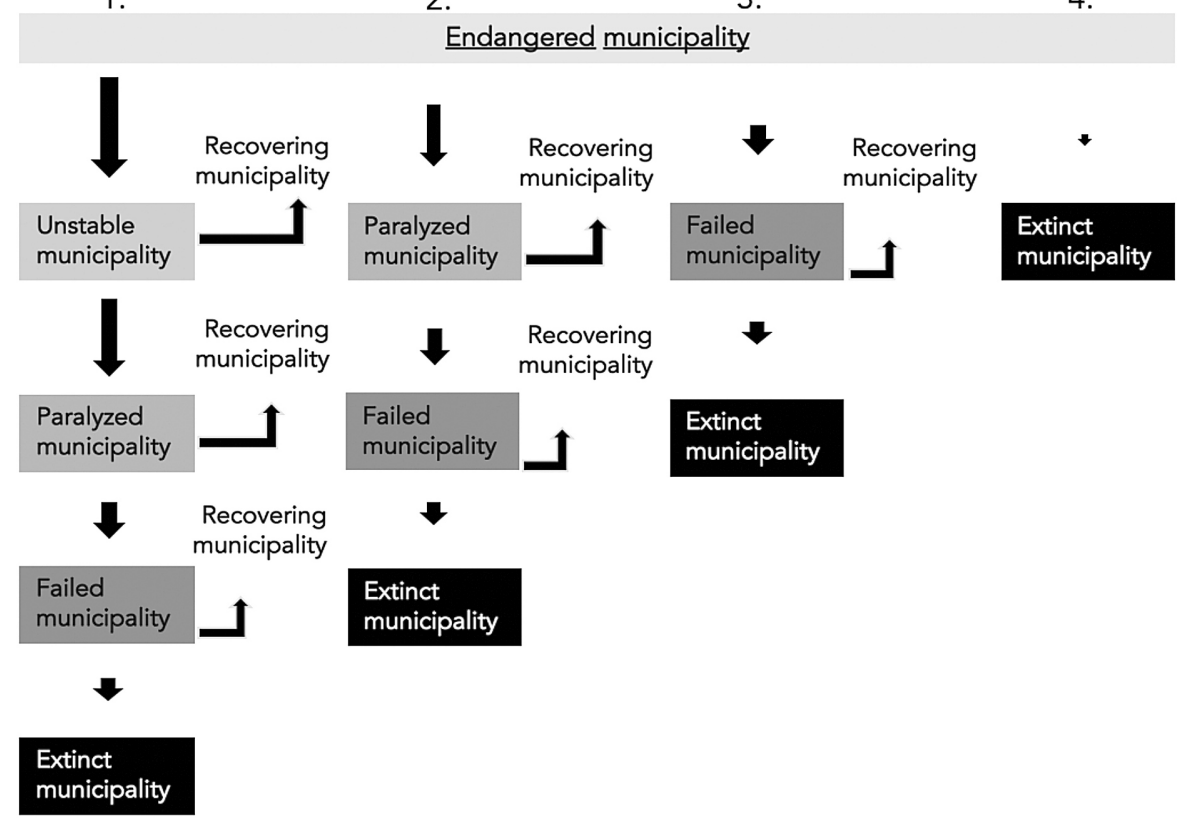

The first variant represents a progressing and deepening path that can lead to the very extinction of the municipality. It can occur in any type of endangerment, yet it is to be expected that the extinction will most likely not occur because in most cases the problem is being solved before the extinction materializes, which launches (mostly) the long-term regeneration of the municipality. If we were to assign some endangerments to the first variant, they would include the critical indebtedness of (small) municipalities or the deepening of the unresolved situation in the municipalities with the smallest number of inhabitants. The second and third variants represent a more rapid momentum of endangerment, when the threat hits the municipality more unexpectedly. For this reason, these

56 The size/length of the arrows in the presented schemes attempts to outline the author's view of the possible deepening of endangerment. The smaller/shorter the arrow, the less likely it is to move to the stage which the arrow is pointing to. 
two variants can be associated primarily with endangerments stemming from natural-environmental threats or war conflicts. The same is true for the fourth variant, except that the extinction of the municipality is not preceded by any other situation in the municipality. The municipality has been so deeply affected that it has been decided not to renew the municipality and thus to cease its existence.

\section{Scheme 2: Scheme of possible variants of endangerment}

5.

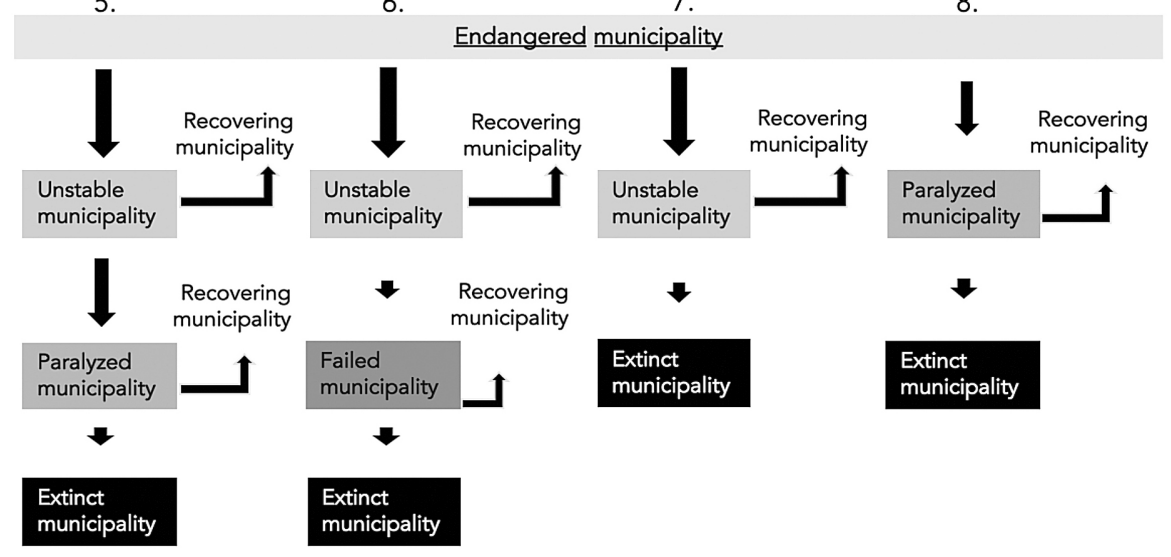

Variants five and six are very similar in their essence to variant one. The main difference in variant number five is that there is no situation where the municipality does not have political leadership, but still the affected municipality may become extinct. Variant number six, on the contrary, represents a more pronounced and faster deepening of the situation. An unstable municipality moves directly to the state where the municipalities are not administered any longer and are directly facing extinction. Under variant number seven, the endangerment posed by a higher intent can best be imagined; a case when a municipality is in a precarious situation and tries to prevent its extinction, yet it has been decided from the higher places about the extinction of the municipality. The eighth variant extends variants two and three where, especially in the case of natural-environmental disasters, paralysis can occur and it has been decided after a subsequent assessment of the situation that the affected municipality will not recover and will cease to exist.On the basis of the presented paper, it can be concluded that small European municipalities are the most vulnerable. In addition to their demographic problems, they mostly operate with small budgets, so they can only provide their citizens with a limited set of municipal services. In the situations where small municipalities are not gaining any new inhabitants, they may over time end up being extinct due to a lack of 
population. If they are more deeply indebted, the smallest municipalities find it hard to repay their debts and often have to restrict or relinquish their services completely. (Not only) This can cause people to leave and to take no interest in communal politics. Even in the case of endangerments by a higher intent, it is to be expected that the municipality's extinction will rather be thought about in the intentions of a smaller municipality than larger agglomerations. A municipality with fewer inhabitants will be less likely able to protect itself from such an intent than a larger one. In a situation where a small municipality is hit by natural and environmental disasters, it can also be expected that it will be less able to cope with the consequences and will rather need help of its surrounding. In the case of potential war conflicts, the smaller municipalities may not be restored after the conflict. This list may also be one of the reasons why consolidation reforms have been implemented in a number of European countries and we cannot find small municipalities in them with fewer than 1,000 inhabitants. The study has aimed to launch a scholarly discussion about the phenomenon of endangered municipalities that are located in functional, legal and democratic states. At the same time I have sought to bring this issue into the realm of political science. It is advisable to expand the number of case studies that would focus on the political impacts in endangered municipalities, both at the horizontal and vertical levels. They could build on examples from the Czech Republic that have so far only been partially mapped.

\section{References}

Alexander, E. David. (2012): L'Aquila earthquake of 2009 offers lessons in disaster response. European Commission (12 January): available at http://ec.europa.eu/environment/integration/research/newsalert/pdf/268na2_en.pdf (2 November 2016)

Al Jazeera (2013): Spanish city faces severe poverty (10 January): available at https://www.aljazeera.com/news/europe/2013/01/2013110183156148250.html (3 March 2016).

Attaching (2017): Bürgerinitiative (10 February): available at http://www.attaching.de/bi-attaching.html (17 June 2017).

Baldersheim, Harald - Rose, E. Lawrence, eds. (2010). Territorial Choice. The Politics of Boundaries and Borders, London: Palgrave Macmillan.

Baroch, Pavel. (2013): Stroj času: Jiřetín slaví 750 let, prezident Zeman ho chce pohřbít, iDnes. cz (7 November): available at https://cestovani.idnes.cz/horni-jiretin-stroj-casu-0xt-/po-cesku. aspx?c=A131106_111851_po-cesku_tom (10 November 2018).

Bartl, Walter (2011): Personalpolitik in schrumpfenden Kommunen. Ostdeutschland, Westdeutschland und Polen im Vergleich, Wiesbaden: VS Verlag für Sozialwissenschaften.

BBC (2005): Montserrat evacuation remembered (12 September): available at http://news.bbc. co.uk/2/hi/americas/4237882.stm (10 October 2018). 
Berner Zeitung (2014): Wallis verliert 19-Seelen-Gemeinde (5 January): available at http://www. bernerzeitung.ch/schweiz/standard/Wallis-verliert19SeelenGemeinde/13944023/print.html (3 March, 2016).

Blore, Ian - Devas, Nick - Slater, Richard (2004): Municipalities and Finance. A Sourcebook for Capacity Building, London: Earthscan.

Bourquard, Georges (2015): Et les villes françaises les plus endettées sont, Ledauphine.com (5. January): available at https://www.ledauphine.com/isere-sud/2015/01/05/et-les-villes-francaises-les-plus-endettees-sont (14 July, 2017).

Brancati, Dawn (2007): Political Aftershocks: The Impact of Earthquakes on Intrastate Conflict, Journal of Conflict Resolution 51 (5): 715-743.

Brand, Stephan (2014). Kommunale Insolvenz und Kommunalrating als Steuerungsinstrumente einer nachhaltigen kommunalen Finanz- und Haushaltspolitik. Münster: LIT Verlag Münster.

Brulle Du, Christian (2014): Mapping Europe's earthquake risk. Horizon - The EU Research \& Innovation Magazine (3 March): available at https://horizon-magazine.eu/article/mapping-europe-s-earthquake-risk_en.html (14 September, 2017).

Burth, Andreas (2015): Zehn am höchsten verchuldete Gemeinden zum 31. 12. 2013, Haushaltsteureung.de (3 April): available at http://www.haushaltssteuerung.de/weblog-schuldenfreie-gemeinden-in-oesterreich.html\#hoechstverschuldete-gemeinden (10 May 2016).

Čas.sk (2015): Ako bačujú naši primátori? TOP 20 najzadlženejších miest Slvenska!, Nový čas (6 October): available at http://www.cas.sk/clanok/332351/ako-bacuju-nasi-primatori-top-20najzadlzenejsich-miest-slovenska/ (18 May 2016).

CEMR (2009). The economic and financial crisis. The impact on local and regional authorities. Second survey, Paris: CEMR.

ČSÚ (2017): Demografické údaje za obce, Český statistický úřad (19 December): available at https://www.czso.cz/csu/czso/databaze-demografickych-udaju-za-obce-cr (19 December 2017).

Davey, Kenneth, ed. (2012): Local Government in Critical Times: Policies for Crisis, Recovery and a Sustainable Future. Strasbourg: Council of Europe Centre of Expertise for Local Government Reform.

Destatis (2016): Gemeindeverzeichnis-Informationssystem (GV-ISys), Statistiches Bundesamt (31 December): available at https://www.destatis.de/DE/ZahlenFakten/LaenderRegionen/Regionales/Gemeindeverzeichnis/Administrativ/AdministrativeUebersicht.html (4 October 2018).

Dolanská, Jitka (2016): Lidé v Pramenech věří, že se zadlužená obec zase svobodně nadechne, iDnes.cz. (1 October): available at http://vary.idnes.cz/prameny-tizi-dluhy-zivot-v-obci-dnf-/ vary-zpravy.aspx?c=A160927_2275690_vary-zpravy_ba (18 November 2016).

Drulák, Petr et al. (2008): Jak zkoumat politiku. Prague: Portál.

Eddy, Melissa (2013): Germany's Rust Belt, a Polished but Ailing City, The New York Times (24 December): available at http://www.nytimes.com/2013/12/25/world/europe/in-germanys-rust-belt-a-polished-but-ailing-city.html, (2 March 2016)

Enca (2015): Eskom moves to leave 20 municipalities in the dark (10 April): available at https:// www.enca.com/south-africa/eskom-moves-leave-20-municipalities-dark (21 June 2016) 
Eurostat (2017): Local Administrative Units (14 January): available at http://ec.europa.eu/eurostat/web/nuts/local-administrative-units (31 May 2017).

Fakt24.pl (2015): Najbardziej zadłużone miasta w Polsce (25 July): available at http://www.fakt. pl/wydarzenia/polityka/najbardziej-zadluzone-miasta-w-polsce/jrymygp (28 October 2016).

Fernández, María (2013): The local councils that are running the risk of bankruptcy, El Pais (22 July): available at http://elpais.com/elpais/2013/07/22/inenglish/1374496783_970511.html (2 March 2016).

FFP (2016): Fragile States Index, The Found for Peace (30 December): available at http://fsi. fundforpeace.org (30 December 2016).

Frankel, Tamar (2014): Municipalities in Distress: A Preventive View, Boston University School of Law (15 January): available at https://www.bu.edu/rbfl/files/2014/03/RBFL-Vol-33.2_Frankel. pdf (19 July 2016).

Geißler, René (2011). Kommunale Haushaltskonsolidierung: Einflussfaktoren lokaler Konsolidierungspolitik. Berlin: Springer-Verlag

Gillette, Clayton P. - Skeel, David A. (2016): Governance Reform and the Judicial Role in Municipal Bankruptcy, The Yale Law Journal 125 (5): available at http://www.yalelawjournal.org/article/ governance-reform-and-the-judicial-role-in-municipal-bankruptcy (20 September 2016).

Glock, Birgit (2006). Stadtpolitik in schrumpfenden Städten. Wiesbaden: VS Verlag.

Gomez, Anna (2015): La fusión de municipios con menos de 5.000 habitantes avanza a paso de tortuga, El Confidencial (6 July): available at http://www.elconfidencial.com/espana/2015-07-06/ reforma-local-fusion-de-municipios-oza-cesuras_915021 (13 October 2016).

Gonzáles, Jesus S. (2013): Andalusia is the region with the most indebted town and city halls, El País (19 April): available at http://elpais.com/elpais/2013/04/19/inenglish/1366394844_000064. html (2 March 2016).

Gosálvez, Patricia (2015): Un país con pueblos de 10 vecinos, El País (13 May): available at http:// politica.elpais.com/politica/2015/05/06/actualidad/1430922820_262841.html (13 October 2016).

Govan, Fiona (2012): Spain's most indebted village pays the price of its profligacy, The Telegraph (11 May): available at http://www.telegraph.co.uk/news/worldnews/europe/spain/9260638/ Spains-mostindebted-village-pays-the-price-of-its-profligacy.html (3 March 2016).

Guha-Sapir, Debarati - Santos, Indhira (2013): The Economic Impacts of Natural Disasters. Oxford: Oxford University Press.

Gulde, Alexander - Locher, Alexander (2015) [Personal interview with staff of the Gemeindeamt (Municipality office) of the canton of Zürich], 27 November.

Hansmann, Marc, ed. (2011): Kommunalfinanzen in der Krise. Problemlagen und Handlungsansätze. Berlin: Berliner Wissenschafts-Verlag.

Hartnoll, R. ed. (2003). Př́ručka k provádění výběru metodou sněhové koule. Snowball Sampling. Prague: Úřad vlády České republiky. 
Hava, Ergin (2015): Turkish municipal debt to hit historic high amid limited audits. Today's Zaman (14 March): available at http://www.todayszaman.com/anasayfa_turkish-municipal-debt-to-hit-historic-high-amid-limited-audits_376175.html (11 May 2016).

Hermida, Xosé. 2013. Galicia aprueba la primera fusión de municipios en España desde 1981. El País (6 June): available at http://ccaa.elpais.com/ccaa/2013/06/06/galicia/1370517797_044761. html (25 November 2016).

Hladný, Josef (2007): Fakta a mýty o povodních, in: Langhammer, Jakub, ed. Povodně a změny $v$ krajině. Prague: Faculty of Sciences, Charles University and Ministry of the Environment of the Czech Republic,

Holtkamp, Lars (2010): Kommunale Haushaltspolitik bei leeren Kassen. Berlin: Edition Sigma.

Holtkamp, Lars (2011): Kommunale Krisenstratefien bei leeren Kassen, in Hansmann Marc, ed., Kommunalfinanzen in der Krise. Problemlagen und Handlungsansätze, 238-254, Berlin: Berliner Wissenschafts-Verlag.

Hornek, Jakub (2016): Politické dopady zadlužování malých obcí v ČR. Případová studie Karlovarského kraje 2010-2014. Prague: Sociologické nakladatelství - SLON.

Hornek, Jakub (2017): Komunální politika v malých bohatých obcích v České republice: politické souboje o zastupitelská křesla či všestranná kooperace ve prospěch obcí? Scientia et Societas 13 (4):115-143.

Ineko (2016): Hospodárenie miest, obcí a vúc (14 December): available at http://www.hospodarenieobci.sk (17 February 2017).

INSEE (2016): Populations légales (3 July): available at http://www.insee.fr/fr/ppp/bases-de-donnees/recensement/populations-legales/default.asp (8 February, 2017).

Instituto Nacional de Estadística (INE) (2016): Cifras oficiales de población resultantes de la revisión del Padrón municipal a 1 de enero (3 July): available at http://www.ine.es/dynt3/ inebase/es/index.html?padre=517 \& dh=1 (8 February 2017).

Junkernheinrich, Martin (2011): Wege aus der kommunalen Schuldenfalle. Konzept zur Lösung des Kassenkreditproblems, in Hansmann, Marc, ed., Kommunalfinanzen in der Krise. Problemlagen und Handlungsansätze, Berlin: Berliner Wissenschafts-Verlag: 115-138.

Kimmel, Tatjana (2006): Eine Stadt geht baden. Zeitonline.de (1 June): available at https://www. zeit.de/2006/23/Eine_Stadt_geht_baden (31 October 2016).

Kingdon, John (1984): Agendas, Alternatives, and Public Policies. Boston: Little Brown.

Knieling, Jörg - Othengrafen, Frank, eds. (2016): Cities in Crisis. Socio-spatial Impacts of the Economic Crisis in Southern European Cities. New York: Routledge.

Krčmárik, Radovan (2015): Samosprávy hospodária lepšie ako štát. Vynimkou je Devín, ktorý má dlhy ako Grécko, Aktuálne.sk (16 August): available at http://aktualne.atlas.sk/samospravy-hospodaria-lepsie-ako-stat-vynimkou-je-devin-ktory-ma-dlhy-ako-grecko/ekonomika/ slovensko-a-ekonomika/ (18 May 2016).

Kühn, Manfred - Liebmann, Heike, eds. (2009): Regenerierung der Städte. Strategien der Politik und Planung im Schrumpfungskontext. Wiesbaden: VS Verlag für Sozialwissenschaften. 
Kursdorf (2009): Warum Web-Seiten über Kursdorf?, Kursdorf (14 October): available at http:// www.kursdorf.net/0030/.

Langhammer, Jakub, ed. (2007): Povodně a změny v krajině. Prague: Faculty of Sciences, Charles University and Czech Ministry of the Environment.

Liptáková, Jana (2017): Devín je v nútenej správe už dvanást́ rokov. SME (24 January): available at https://bratislava.sme.sk/c/20440530/devin-je-v-nutenej-sprave-uz-dvanast-rokov. html\#ixzz5YNMr6xoR.

Marrian, Natasha - Magubane, Khulekani (2014): Treasury admits failure with municipalities, BDlive (10 December): available at http://www.bdlive.co.za/national/2014/12/10/treasury-admits-failure-with-municipalities (20 May 2017).

Meinbezirk.at (2015): Finden Sie hier heraus, wie viele Schulden Ihre Gemeinde hat (2 March): available at https://www.meinbezirk.at/land-oesterreich/wirtschaft/finden-sie-hier-heraus-wie-viele-schulden-ihre-gemeinde-hat-d1259219.html (19 May 2016).

Milerová, Květoslava (2016): [E-mail correspondence with employee of the Department of Administrative Affairs and Regional Trade Office, Ústí nad Labem], 20 April.

Ministry of the Environment of the Czech Republic (2009): Vyhodnocení povodní v červnu a v červenci 2009 na území České republiky. Prague: Czech Environment Ministry.

Mittermeir, Alexander (2015): Deutschland: Die 10 Städte mit den höchsten Pro-Kopf-Schulden, GeVestor.de (13 July): available at http://www.gevestor.de/details/deutschland-die-10-staedte-mit-den-hoechsten-pro-kopf-schulden-744104.html (19 December, 2016).

Mongaillard, Vincent (2013): Comment fait-on... pour élire un maire dans une commune de 1 habitant? Le Parisien.fr (5 December): available at http://www.leparisien.fr/municipales-2014/ comment-fait-on-pour-elire-un-maire-dans-une-commune-de-1-habitant-05-12-2013-3379003. php (11 February 2017).

Oswalt, Philipp, ed. (2004): Schrumpfende Städte. Band 1: Internationale Untersuchung. Ostfildern-Ruit: Hatje Cantz Verlag.

Oswalt, Philipp, ed. (2006): Atlas of Shrinking Cities. Atlas der schrumpfenden Städte. Ostfildern: Hatje Cantz Verlag.

Otriová, Jana (2017): Ondavka je slovenskou raritou. Nemá starostu ani poslancov, Korzár Prešov (23 October): available at https://presov.korzar.sme.sk/c/20677988/ondavka-je-slovenskou-raritou-nema-starostu-ani-poslancov.html (14 September 2018).

Pelling, Mark - Wisner, Ben, eds. (2014): Disaster Risk Reduction. Cases from Urban Africa. New York: Earthscan from Routledge.

Périnel, Quentin (2016): Le classement des villes françaises les plus endettées, LeFigaro. fr (14 October): available at http://www.lefigaro.fr/economie/le-scan-eco/dessous-chiffres/2016/10/14/29006-20161014ARTFIG00164-le-classement-des-villes-francaises-les-plus-endettees.php (13 February 2018).

Portugal News (2016): Portimão gets debt relief (5 October): available at http://theportugalnews. com/news/portimao-gets-debt-relief/39737 (14 October 2018). 
Radačičová, Simone (2016): Italský premiér slibuje obnovu oblasti, ale je to úkol na roky (26-28 August).

Reinero, David (2016): Los municipios gallegos de Cotobade y Cerdedo unen sus Ayuntamientos, El País (23 February): available at http://politica.elpais.com/politica/2016/02/23/actualidad/1456233174_316373.html (19 December 2016).

Richter, Ralph (2013): Nach dem Schrumpfen. Stadtbezogene Identität als Potenzial schrumpfender Städte. Berlin: Frank \& Timme.

Roads, Edward Thomas. (2015). The Nine Villages Détruits (Destroyed) at Verdun, Roads to the Great War (25 November 2015): available at http://roadstothegreatwar-ww1.blogspot. com/2015/11/the-nine-villages-detruits-destroyed-at.html (14 October 2018).

Sąsiada, Tomasz (2015): Słupsk na skraju bankructwa? Te miasta są zadłużone jeszcze bardziej!, Money.pl (16 August): available at http://www.money.pl/gospodarka/wiadomosci/artykul/ slupsk-na-skraju-bankructwa-te-miasta-sa,77,10,1847373.html (18 November 2016).

Schneider, Saundra K. (2011): Dealing with Disaster. Public Management in Crisis Situations. London \& New York: Routledge.

Schragger, Richard (2016): City Power. Urban Governance in a Global Age, Oxford: Oxford University Press.

Schweizer Bauer (2018). Die kleinste Gemeinde der Schweiz (2 June): available at https://www. schweizerbauer.ch/vermischtes/allerlei/die-kleinste-gemeinde-der-schweiz-42544.html (14 October 2018).

Secolo d'Italia.it (2014): I Comuni di sinistra sono i più indebitati d'Italia. Ecco la classifica (30 October): available at http://www.secoloditalia.it/2014/10/i-comuni-sinistra-i-indebitati-ditalia-classifica/ (18 July 2017).

Skrobisz, Dorota (2015): Kandydaci na bankrutów-coraz ich więcej. Wałbrzych, Stupsk, Chełm, Niezalezna.pl (20 September): available at http://niezalezna.pl/71082-kandydaci-na-bankrutow-coraz-ich-wiecej-walbrzych-slupsk-chelm (18 November 2016).

Slovenia News (2018): Local Elections: Most Municipalities in Debt Due to Wide Range of Responsibilities. Total Slovenia News (13 November): available at https://www.total-slovenia-news. com/politics/2467-slovenian-local-politics-most-municipalities-in-debt-due-to-wide-range-of-responsibilities-feature (15 November 2018).

Šmíd, Tomáš - Vad'ura, Vladímír (2009): Teoretické vymezení a konceptualizace fenoménu slabých a selhávajících států, Mezinárodní vztahy 44 (2): 44-64.

Smithsonian Institution (2016): Global Volcanism Program, Smithsonian Institution, National Museum of Natural History (30 December): available at http://volcano.si.edu (30 December 2016).

Sobotainfo.com. (2013) Dolg slovenskih občin blizu milijarde evrov, rekorderka občina Gornji Petrovci (12 September): available at http://sobotainfo.com/novica/lokalno/dolg-slovenskih-obcin-blizu-milijarde-evrov-rekorderka-obcina-gornji-petrovci/32676 (18 May 2016).

Spěváčková, Martina (2016): Dluh přes milion na hlavu. Investice do vrtů Prameny sráží, nejzadluženější obec však neumírá, Rozhlas.cz (14 August): available at http://www.rozhlas.cz/zpravy/regiony/_zprava/dluh-pres-milion-na-hlavu-investice-do-vrtu-prameny-srazi-nejzadluzenejsi-obec-vsak-neumira-1641135 (11 February 2017). 
Spiotto, James E. - Acker, Ann E. - Appleby, Laura E. (2012): Municipalities in Distress? How States and Investors Deal with Local Government Financial Emergencies. Middletown: Chapman and Cutler.

Štatistický úrad (2016): Obyvatel'stvo a migrácia. Štatistický úrad Slovenskej republiky (3 July): available at (https://slovak.statistics.sk/wps/portal/ext/themes/demography/population/ indicators (3 July 2016).

Statistik Schweiz (2018): Statisticher Atlas der Schweiz, Statistik Schweiz (10 October): available at https://www.atlas.bfs.admin.ch/maps/13/map/mapldOnly/8721_de.html (10 October 2018).

Statistik.at (2016): Gemeinden, Gemeindeverbände, (3 July): available at http://www.statistik.at/ web_de/statistiken/wirtschaft/oeffentliche_finanzen_und_steuern/oeffentliche_finanzen/ gebarungen_der_oeffentlichen_rechtstraeger/index.html (3 July 2016).

Teevs, Christian (2013): Das Schuldendorf der Schweiz, Spiegel.de (9 December): available at http://www.spiegel.de/wirtschaft/soziales/schweizer-dorf-leukerbad-kaempft-gegen-seine-geschichte-a-937206.html (30 October 2016).

Tunega, Matej (2015): Aj napriek pomoci štátu má nad'alej najvyšší dlh Žilina, SME.sk (5 October): available at http://ineko.blog.sme.sk/c/388427/aj-napriek-pomoci-statu-ma-nadalej-najvyssi-dlh-zilina.html (18 May 2016).

Tvnoviny.sk (2018). Ondavka nemá kandidáta na starostu, obec možno zanikne, Tvnoviny.sk (16 September): available at http://www.tvnoviny.sk/domace/1934904_ondavka-nema-kandidata-na-starostu-obec-mozno-zanikne (20 September 2018).

UCLG (2009): The Impact of the Global Crisis on Local Government. Barcelona: UCLG.

United Nations (2018): $68 \%$ of the world population projected to live in urban areas by 2050, says UN (16 May) available at https://www.un.org/development/desa/en/news/population/2018revision-of-world-urbanization-prospects.html.

Válasz.hu (2013): Rendezte az állam a 14 kistelepülés adósságát (13 May): available at http:// valasz.hu/uzlet/az-erintett-telepuleseken-gyogy-es-elmenyfurdot-idosotthon-epult-63847 (30 October 2016).

Vláda SR (2014): Návrh na zníženie sumy a zmenu termínu splatnosti návratnej finančnej výpomoci poskytnutej mestu Žilina (17 December): available at http://www.rokovania.sk/Rokovanie. aspx/BodRokovaniaDetail?idMaterial=24158 (18 May 2016).

Volcano Discovery (2016): Volcanoes, Volcano Discovery (30 December): available at https:// www.volcanodiscovery.com (30 December 2016).

Weaver, Russell - Bagchi-Sen Sharmistha - Knight Jason - Frazier, Amy E. 2017. Shrinking Cities. Abingdon and New York: Routledge.

Welt.de (2013): Erster Sparkommissar NRWs geht mit gutem Gefühl (13 November): available at https://www.welt.de/regionales/koeln/article121854628/Erster-Sparkommissar-NRWs-geht-mit-gutem-Gefuehl.html (20 November 2017).

Wetter, Ann-Kathrin (2014). Die am höchsten verschuldeten Gemeinden in Deutschland, HuffingtonPost.de (12 August): available at https://www.huffingtonpost.de/2014/08/12/verschuldete-gemeinden-hoechsten_n_5671186.html (18 August 2017). 
Wisner, Ben - Luce, R. Henry (1993): Disaster Vulnerability: Scale, Power and Daily Life. GeoJournal 30 (2): 127-140.

WP finance (2016): Nie tylko Wrocław. Oto najbardziej zadłużone miasta w Polsce. WP finance (19 November): available at http://finanse.wp.pl/gid,18599831,kat,1033699,page,11,title, Nie-tylko-Wroclaw-Oto-najbardziej-zadluzone-miasta-w-Polsce, galeria.html (7 May 2017).

Yin, K. Robert (2015): Qualitative Research from Start to Finish. 2ndn edition. New York: Guilford Publications.

Zaniklé obce. (2018). Zaniklé obce a objekty (19 October): available at http://www.zanikleobce. cz (19 October 2018).

Jakub Hornek is a PhD candidate and research assistant at the Institute of Political Studies in the Faculty of Social Sciences at Charles University, Prague. He can be contacted at:jakub.hornek@fsv.cuni.cz. 